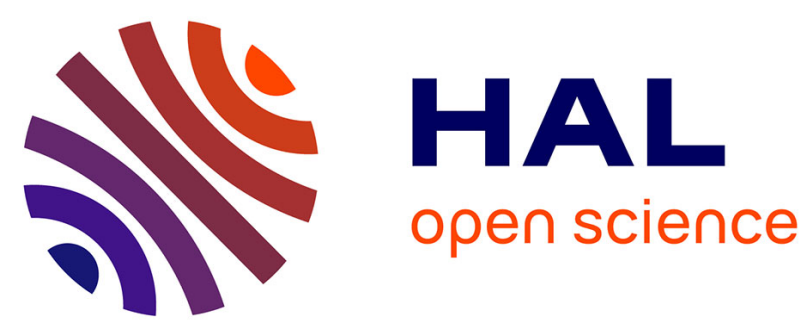

\title{
Wandering Albatrosses Document Latitudinal Variations in the Transfer of Persistent Organic Pollutants and Mercury to Southern Ocean Predators
}

Alice Carravieri, Paco Bustamante, Sabrina Tartu, Alizée Meillere, Pierre Labadie, Hélène Budzinski, Laurent Peluhet, Christophe Barbraud, Henri

Weimerskirch, Olivier Chastel, et al.

\section{To cite this version:}

Alice Carravieri, Paco Bustamante, Sabrina Tartu, Alizée Meillere, Pierre Labadie, et al.. Wandering Albatrosses Document Latitudinal Variations in the Transfer of Persistent Organic Pollutants and Mercury to Southern Ocean Predators. Environmental Science and Technology, 2014, 48 (24), pp.14746-14755. 10.1021/es504601m . hal-02334596

\author{
HAL Id: hal-02334596 \\ https://hal.science/hal-02334596
}

Submitted on 27 Oct 2019

HAL is a multi-disciplinary open access archive for the deposit and dissemination of scientific research documents, whether they are published or not. The documents may come from teaching and research institutions in France or abroad, or from public or private research centers.
L'archive ouverte pluridisciplinaire HAL, est destinée au dépôt et à la diffusion de documents scientifiques de niveau recherche, publiés ou non, émanant des établissements d'enseignement et de recherche français ou étrangers, des laboratoires publics ou privés. 
Wandering albatrosses document latitudinal variations in the bioavailability of persistent organic pollutants and mercury in the Southern Ocean

Alice Carravieri ${ }^{1,2 *}$, Paco Bustamante ${ }^{2}$, Sabrina Tartu ${ }^{1}$, Alizée Meillère ${ }^{1}$, Pierre Labadie $^{3,4}$, Hélène Budzinski ${ }^{3,4}$, Laurent Peluhet ${ }^{3,4}$, Christophe Barbraud ${ }^{1}$, Henri Weimerskirch ${ }^{1}$, Olivier Chastel $^{1}$, Yves Cherel $^{1}$

${ }^{1}$ Centre d'Etudes Biologiques de Chizé (CEBC), UMR 7372 CNRS-Université de La Rochelle, BP 14, 79360 Villiers-en-Bois, France

${ }^{2}$ Littoral Environnement et Sociétés (LIENSs), UMRi 7266 CNRS-Université de la Rochelle, 2 rue Olympe de Gouges, 17000 La Rochelle, France

${ }^{3}$ Université de Bordeaux, UMR 5805 EPOC (LPTC Research group), Université de Bordeaux, 351 Cours de la Libération F_33405 Talence Cedex France

${ }^{4}$ CNRS, UMR 5805 EPOC (LPTC Research group), Université de Bordeaux 351, Cours de la Libération F_33405 Talence Cedex France

*corresponding author: Alice Carravieri CEBC, UMR 7372 CNRS-Université de La Rochelle BP 14,79360 Villiers-en-Bois (France) Tel: +33(0)549099618; Fax: +33(0)549096526 E-mail: alice.carravieri@cebc.cnrs.fr 
ABSTRACT: Top marine predators are effective tools to monitor bioaccumulative contaminants in remote oceanic environments. Here, we used the wide-ranging wandering albatross Diomedea exulans to investigate potential geographical variations of contaminant transfer to predators in the Southern Ocean. Blood concentrations of 19 persistent organic pollutants and 14 trace elements were measured in a large number of individuals $(\mathrm{N}=180)$ of known age, sex and breeding status from the subantarctic Crozet Islands. Wandering albatrosses were exposed to a wide range of contaminants, with notably high blood mercury concentrations. Contaminant burden was markedly influenced by latitudinal foraging habitats (inferred from blood $\delta^{13} \mathrm{C}$ values), with individuals feeding in warmer subtropical waters having lower concentrations of pesticides, but higher concentrations of mercury, than those feeding in colder subantarctic waters. Sexual differences in contaminant burden seemed to be driven by gender specialization in feeding habitats, rather than physiological characteristics, with females foraging further north than males. Other individual traits, such as adult age and reproductive status, had little effect on blood contaminant concentrations. Our study provides further evidence of the critical role of global distillation on organic contaminant exposure to Southern Ocean avian predators. In addition, we document an unexpected high transfer of mercury to predators in subtropical waters, which merits further investigation.

Key words: Antarctica, Cadmium, Mercury, POPs, Procellariiformes, Stable isotopes 


\section{INTRODUCTION}

Anthropogenic activities have released intentionally and non-intentionally hundreds of thousands of different chemical compounds into the environment. Among these, persistent organic pollutants (POPs) such as organochlorine pesticides (OCPs), polychlorinated biphenyls (PCBs), and polybrominated diphenyl ethers (PBDEs) are of great concern, because they were designed to resist degradation for their agricultural and industrial applications. ${ }^{1,2}$ Additionally, human activities have increased emissions to the environment of natural trace elements, such as metals and metalloids, raising their concentrations in a variety of ecosystems worldwide. ${ }^{3}$ POPs and both essential and nonessential trace elements can be toxic for humans and wildlife., ${ }^{4,5}$ Moreover, some environmental contaminants, such as POPs and mercury $(\mathrm{Hg})$, bioaccumulate in biota and biomagnify up food webs. ${ }^{6,7}$ POPs and $\mathrm{Hg}$ also undergo long-range atmospheric transport and deposition, ${ }^{8,9}$ contributing to the nonpoint source contamination of remote environments. The World Ocean in particular appears to be the last sink for some POPs and trace elements, ${ }^{8,10,11}$ but few data are available on their distribution and trophic transfer in remote oceanic areas. ${ }^{12,13}$ This is particularly true for the southern Indian Ocean, where POPs $^{14-18}$ and trace elements ${ }^{19-28}$ have been measured in only some biota, while information on water concentrations lacks dramatically. ${ }^{12,29,30}$ While direct assessment of environmental contaminants in large open water regions is logistically challenging, great insight into patterns of marine contamination can be obtained by using top predators as bioindicators. ${ }^{31}$ Seabirds, in particular, have revealed important geographical trends of contaminant transfer to predators in a variety of ecosystems. ${ }^{32,33}$ Yet, many different factors can drive variation in seabird exposure, hampering their use as reliable bioindicators of marine contamination. ${ }^{34}$ Variability in seabird POP and trace element concentrations results not only from extrinsic factors, such as feeding habitat and trophic position, ${ }^{27,35,36}$ but also from intrinsic factors, such as detoxification capability and nutritional condition. ${ }^{2,37}$ Intraspecific variation in contaminant exposure has received substantial consideration (e.g., ref 38), yet marked between individual differences often remain largely unexplained. ${ }^{39,40}$ Overall, there is a need for more studies that concurrently assess a wide range of causal ecological factors. In particular, life-history traits have been rarely considered, ${ }^{41,42}$ due to the paucity of long-term surveys on seabird populations giving access to individuals of known age and breeding history. ${ }^{28,43,44}$

The present study evaluates POP and trace element concentrations in a large number of known individual wandering albatrosses Diomedea exulans, breeding at the subantarctic Crozet Islands, southern Indian Ocean. Blood was used as monitoring tissue, since circulating contaminants are known to reflect internal tissues concentrations. ${ }^{45,46}$ The wandering albatross 
is an extremely long-lived ( $>50$ years) cephalopod-eating seabird with one of the highest trophic levels among marine consumers of the Southern Ocean. ${ }^{24,47}$ This top predator is thus potentially exposed to large quantities of contaminants through bioaccumulation mechanisms, as shown for $\mathrm{Hg}^{24,48,49}$ During the breeding period (a whole year) wandering albatrosses are central-place foragers and undertake large scale movements, foraging up to $3500 \mathrm{~km}$ from their nest, thus ranging from subtropical to Antarctic waters. ${ }^{50,51}$ This provides an exceptional opportunity to investigate contaminant trophic transfer over a large latitudinal range from one single species of apex predator.

The objectives of this investigation were 3 -fold. First, contaminant concentrations of the wandering albatross were described and compared to those found in closely related species worldwide, in order to set results from this study in a global context. Second, by combining information on individual traits from a long-term capture-mark-recapture survey and by using the stable isotope ratios of carbon $\left(\delta^{13} \mathrm{C}\right)$ and nitrogen $\left(\delta^{15} \mathrm{~N}\right)$ as trophic tracers, we assessed the relative contribution of intrinsic (sex, age, and breeding status) and extrinsic (feeding ecology) factors on contaminant burden. The final aim of this study was to infer potential latitudinal trends in contaminant transfer to predators in the southern Indian Ocean. Feeding ecology was expected to be more relevant than intrinsic traits in explaining between-individual variation in contaminant concentrations. ${ }^{27,48}$ Both POP and $\mathrm{Hg}$ burdens were predicted to be higher in individuals feeding in cold subantarctic waters than in those feeding in the subtropics, since polar environmental characteristics (e.g., low temperature, winter darkness) favour the atmospheric deposition and persistence of these contaminants. ${ }^{1,8,9}$

\section{MATERIAL AND METHODS}

Study site and sampling procedure. The study was carried out on Possession Island, Crozet Archipelago $\left(46^{\circ} \mathrm{S}, 52^{\circ} \mathrm{E}\right)$. The island lies in the Subantarctic Zone that corresponds to the water masses situated between the northern and warmer Subtropical Zone and the southern and colder Antarctic Zone. ${ }^{52}$ Adult wandering albatrosses return to their breeding grounds in December and females lay a single egg in late December to early January. Both parents incubate alternatively until hatching in March and most young are fledged in November. During the incubation period (21 December to 4 March 2008), a total of 180 wandering albatrosses were sampled, including breeding and nonbreeding individuals. All birds were of known age (3-49 years), sex and breeding status, since they are part of a long-term capture-mark-recapture program started in $1966 .{ }^{53}$ Blood was taken from the tarsal vein with a $1 \mathrm{~mL}$ heparinized syringe 
and a 25-gauge needle. Plasma and red blood cells were separated by centrifugation and stored at $-20^{\circ} \mathrm{C}$. POPs and trace elements were measured in plasma and red blood cells, respectively, where they preferentially partition. ${ }^{49,54,55}$ Hence, "blood" within the whole text refers either to plasma for POPs or red blood cells for trace elements.

POP and trace element analyses. POPs were measured at the laboratory EPOC-LPTC, Bordeaux, France, from plasma ( $\mathrm{N}=128,100 \mu \mathrm{l}$ aliquots). Targeted compounds included seven indicator PCBs (CB-28, -52, -101, -118, -138, -153 and -180), 11 OCPs (hexachlorobenzene: $\mathrm{HCB}$; lindane: $\gamma-\mathrm{HCH}$; heptachlore; cis-chlordane; trans-nonachlor; mirex; 2,4'-DDE; 4,4'DDE; 4,4'-DDD; 2,4'-DDT; 4,4'-DDT) and one PBDE (BDE-47). POPs were quantified using gas chromatography coupled with electron capture detection (GC-ECD). The percentage of total lipids in plasma was also measured on an aliquot of $10 \mu \mathrm{L}$ by the sulfo-phospho-vanillin (SPV) method for colorimetric determination. ${ }^{56}$ POP results are given in both absolute concentrations in $\mathrm{ng} \mathrm{g}^{-1}$ wet weight (ww) and relative to the plasma lipid weight (lw).

Fourteen trace elements were measured on lyophilized red blood cells at the laboratory LIENSs, La Rochelle, France. Total Hg was quantified with an Altec AMA 254 spectrophotometer ( $\mathrm{N}=$ 169, aliquots mass: 5-10 mg dry weight, dw), while arsenic (As), chromium (Cr), copper $(\mathrm{Cu})$, iron $(\mathrm{Fe})$, manganese $(\mathrm{Mn})$, nickel $(\mathrm{Ni})$, selenium $(\mathrm{Se})$ and zinc $(\mathrm{Zn})$ were analysed using a Varian Vista-Pro ICP-OES and silver (Ag), cadmium (Cd), cobalt (Co), lead (Pb) and vanadium (V) using a Series II Thermo Fisher Scientific ICP-MS ( $\mathrm{N}=165$, aliquots mass: 20-200 mg $\mathrm{dw})$. Results are presented in absolute concentrations in $\mu \mathrm{g} \mathrm{g}^{-1} \mathrm{dw}$.

Quality Control/Quality Assessment and other details about POP and trace element analyses are given in the Supporting Information (SI) (first paragraph and Table S1). All results are given as means \pm SD. Since POP distributions were asymmetric, especially for PCBs, median rather than mean values were used for comparisons with the literature.

Stable isotope method. The isotopic niche of albatrosses was used as a proxy of their ecological niche. ${ }^{57}$ The isotopic method was validated in the southern Indian Ocean, with $\delta^{13} \mathrm{C}$ values of seabirds indicating their foraging habitats ${ }^{50,58}$ and their $\delta^{15} \mathrm{~N}$ values increasing with trophic level. ${ }^{59}$ The isotopic method is based on time-integrated assimilated food, with different tissues recording trophic information at different time scales. In this study, $\delta^{13} \mathrm{C}$ and $\delta^{15} \mathrm{~N}$ values were measured in red blood cells, which provide trophic information on a few weeks before sampling, ${ }^{60}$ thus corresponding here to the incubation period. The effect of blood $\delta^{13} \mathrm{C}$ and $\delta^{15} \mathrm{~N}$ values on contaminant exposure was investigated using an isotopic data set that was built to study the effect of age, sex and breeding status on foraging strategies of the wandering 
albatross. ${ }^{61}$ Results are given in \%o as means \pm SD. Details about stable isotope analyses are given in the SI.

Statistical analyses. All statistical analyses were performed using R 2.15.1. ${ }^{62}$ Only POP and trace element concentrations that were above the limit of quantification (LoQ) in at least $70 \%$ of individuals were included in statistical analyses. For these POPs and trace elements, concentrations below the LoQ were substituted using $0.5 \cdot \mathrm{LoQ}$ to avoid missing values distorting the statistical outcomes. Data exploration was carried out following Zuur et al. ${ }^{63}$, with relationships between variables being tested with Pearson or Spearman correlation tests. In a first descriptive step, a principal component analysis (PCA) was carried out on log-transformed POPs and trace elements in order to highlight co-variance. In a second explanatory step, univariate analyses (linear models, LM, or generalized linear models, GLM) were used to test the effect of individual traits and foraging ecology on absolute contaminant concentrations of breeding individuals. As sample sizes differed for POPs and trace elements, separate models were constructed. In order to reduce multiple testing, only the sum of PCBs ( $\left.\Sigma_{7} \mathrm{PCBs}\right)$ and OCPs ( $\Sigma_{11} \mathrm{OCPs}$ ) and the non-essential, potentially harmful $\mathrm{Hg}$ and $\mathrm{Cd}$ were retained as response variables. $\mathrm{Pb}$ and $\mathrm{Ag}$ were not considered as response variables, because the former had quantifiable concentrations in less than $70 \%$ of individuals, and the latter explained poorly the total variation in the PCA data set (see variable loadings on principal component axis in in Table S2, SI). The $\Sigma_{7} \mathrm{PCBs}$ and $\Sigma_{11} \mathrm{OCPs}$ were correlated to individual PCBs and OCPs, respectively (Pearson correlation, $0.48<r<0.94$ for PCBs and $0.28<r<0.97$ for OCPs, all $p$ $<0.01, \mathrm{~N}=83$ ), with the exception of 2,4' DDT and heptachlor for OCPs $(r=0.12$ and $0.05, p$ $=0.289$ and 0.623 , respectively). Only biologically meaningful models were constructed, with the maximal model being Contaminant $\sim \delta^{13} \mathrm{C}+\operatorname{sex}+$ age $+\delta^{13} \mathrm{C}: \mathrm{sex}+\delta^{13} \mathrm{C}$ :age (with ":" indicating the interaction between the variables). The percentage of lipids in plasma (hereafter lipid) was also included as a covariate in models explaining $\Sigma_{11}$ OCPs and $\Sigma_{7}$ PCBs values. Blood $\delta^{15} \mathrm{~N}$ was not included in the models, since it was strongly correlated to $\delta^{13} \mathrm{C}$ (Pearson correlation, $r=0.85, p<0.0001, \mathrm{~N}=104)$. This results from the slight, latitudinal enrichment in $\delta^{15} \mathrm{~N}$ values from cold to warm waters of the southern Indian Ocean (see also ref 50). Over the large latitudinal gradient exploited by wandering albatrosses, the trophic-level information on $\delta^{15} \mathrm{~N}$ values is thus confounded by a feeding habitat effect. Forward selection using the Akaike's Information Criterion corrected for small sample sizes (AICc) ${ }^{64}$ was applied. Since our aim was to make inference on the variables affecting contaminant burdens, the effect of variables was inferred through Akaike's weights, and without using model averaging. ${ }^{64}$ Finally, the effect of breeding status was separately tested on males only, since the sample of 
nonbreeding individuals was unbalanced (only three nonbreeding females were analyzed for contaminant concentrations). Breeding status categories thus included male immature (3-11 year-old birds with no known breeding attempts), breeding and nonbreeding individuals. GLMs were constructed in the form Contaminant $\sim$ Breeding status $(+$ lipid, for $\Sigma 110 C P$ s and $\Sigma 7 \mathrm{PCBs}$ ) and hypothesis testing was applied (likelihood ratio test, LRT, between each model and the null model). For all analyses, model specification and validation were based on residuals analysis. ${ }^{65}$

\section{RESULTS}

POP and trace element concentrations and associations. Among the 33 targeted POPs and trace elements, 30 were detected in blood of wandering albatrosses from the Crozet Islands (see Table S3 and S4, SI). The POP pattern was dominated by OCPs (58\% of $\Sigma_{19}$ POPs), with the highest median concentrations being reported for 4,4'-DDE and HCB (5.4 and $1.8 \mathrm{ng} \mathrm{g}^{-1} \mathrm{ww}$, respectively). Other compounds with quantifiable concentrations in most individuals (> 70\%) were 4,4'-DDD, mirex and trans-nonachlor. Noticeably, the isomers 2,4'-DDT and 4,4'-DDT had quantifiable concentrations in more than $60 \%$ of individuals. The $\Sigma_{11} \mathrm{OCPs}$ ranged from 1.3 to $56.0 \mathrm{ng} \mathrm{g}^{-1} \mathrm{ww}$. Indicator PCBs accounted for $40 \%$ of the $\Sigma_{19} \mathrm{POPs}$, with congeners CB-138, CB-153, and CB-180 having quantifiable concentrations in most individuals (> 70\%). The highest median concentration was however reported for CB-118 (2.5 $\left.\mathrm{ng} \mathrm{g}^{-1} \mathrm{ww}\right)$. The $\Sigma_{7} \mathrm{PCBs}$ ranged from 0.1 to $676 \mathrm{ng} \mathrm{g}^{-1} \mathrm{ww}$. Only $18 \%$ of individuals had quantifiable concentrations of BDE-47, with values ranging from < LoQ to $1.9 \mathrm{ng} \mathrm{g}^{-1} \mathrm{ww}$ (BDE-47 accounted for $2 \%$ of $\Sigma_{19}$ POPs). Blood POP concentrations presented large between-individual variation, with coefficients of variation (CVs) being particularly high for PCBs (range 119-296\% Table S3, SI).

Among the 14 trace elements, only three were not detected in any individual (the essential Co, Mn and V), while seven were quantifiable in more than $70 \%$ of individuals, including both essential ( $\mathrm{Cu}, \mathrm{Fe}, \mathrm{Se}, \mathrm{Zn})$ and non-essential $(\mathrm{Ag}, \mathrm{Cd}, \mathrm{Hg})$ elements. Fe and Se reported the highest concentrations among essential elements $\left(2326 \pm 345\right.$ and $77 \pm 33 \mu \mathrm{g} \mathrm{g}^{-1} \mathrm{dw}$, respectively). Notably, $\mathrm{Hg}$ had quantifiable concentrations in all individuals and showed the highest concentrations among non-essential elements $\left(7.7 \pm 3.6 \mu \mathrm{g} \mathrm{g}^{-1} \mathrm{dw}\right)$. Between-individual variation was less pronounced for trace elements than POPs, with the non-essential $\mathrm{Ag}$ and $\mathrm{Pb}$ having the highest CVs (189\% and 95\%, respectively, Table S4, SI). 
PCA analyses included the eight POPs and seven trace elements that had quantifiable concentrations in more than $70 \%$ of individuals (see Table S2, S3, and S4, SI). POPs and $\mathrm{Hg}$ contributed markedly to the total variation in the data set. Strong associations were identified within PCBs and within OCPs, but the two POP classes were not associated with each other as shown by the PCA circle of correlations (Figure S1, SI). Hg was potentially negatively associated to OCPs, but no association with other metals was clearly identified.

Explanatory factors of between-individual variation in exposure. Univariate analyses were applied to disentangle the influence of sex, age and feeding habitat $\left(\delta^{13} \mathrm{C}\right)$ on $\Sigma_{7} \mathrm{PCBs}, \Sigma_{11} \mathrm{OCPs}$, $\mathrm{Hg}$ and $\mathrm{Cd}$ burdens in breeding wandering albatrosses (Table 1). For the $\Sigma_{7} \mathrm{PCBs}$, multiple models had a similar support $(\triangle \mathrm{AICs}<2)$, but explained only $7 \%$ of the total variation (Table 1). Plasma lipid content was clearly the most influential variable, as shown by the sum of Akaike's weights across all models (Table 2). $\Sigma_{7} \mathrm{PCBs}$ concentrations increased with increasing lipid content (Figure S2, SI). Multiple models had a similar support for blood $\Sigma_{11} \mathrm{OCPs}$ concentrations, explaining approximately $20 \%$ of the total variation (Table 1$). \delta^{13} \mathrm{C}$, sex, and lipid were the most important predictor variables (Table 2). Exposure was negatively related to $\delta^{13} \mathrm{C}$ values (Figure 1a). Males and females had $\Sigma_{11}$ OCPs concentrations of $18.4 \pm 10.7$ and $11.1 \pm 6.2 \mathrm{ng}$ g-1 ww, respectively.

One single model best described blood $\mathrm{Hg}$ data, the $\mathrm{LM} \delta^{13} \mathrm{C}+\operatorname{sex}+\delta^{13} \mathrm{C}$ :sex, with a percentage of explained variation of 53\% (Table 1). The sum of Akaike's weights across all models confirmed the strong effect of $\delta^{13} \mathrm{C}$ and sex on $\mathrm{Hg}$ concentrations (Table 2). Unlike the $\Sigma_{11} \mathrm{OCPs}, \mathrm{Hg}$ concentrations were positively related to $\delta^{13} \mathrm{C}$ values (Figure $1 \mathrm{~b}$ ) and were lower in males than in females $\left(6.4 \pm 3.3\right.$ and $10.9 \pm 3.5 \mu \mathrm{g} \mathrm{g}^{-1} \mathrm{dw}$, respectively). Finally, for blood Cd concentrations, multiple models had a similar support, but explained only 5-7\% of the total variation (Table 1). Sex was the factor with the highest sum of Akaike's weights across all models (Table 2). Males had lower Cd concentrations than females (56 \pm 28 and $72 \pm 38 \mu \mathrm{g} \mathrm{g}^{-}$ ${ }^{1} \mathrm{dw}$, respectively).

Notably, age had no significant effect on contaminant exposure for any of the tested contaminants ( $\sum_{7} \mathrm{PCBs}, \sum_{11} \mathrm{OCPs}, \mathrm{Hg}$, and $\mathrm{Cd}$ ), with the sum of Akaike's weights accounting for age ranging only between 0.26 and 0.31 (Table 2).

Breeding status had a significant effect only on the $\Sigma_{7} \mathrm{PCB}$ in males (GLM on log-transformed data, gaussian distribution, identity link function, taking into account the lipid effect, $p=0.01$, $\mathrm{N}=79$ ), with concentrations in non-breeding individuals being higher than in breeding ones. Conversely, $\Sigma_{11} \mathrm{OCPs}, \mathrm{Hg}$ and Cd concentrations were not influenced by breeding status (GLM, gamma distribution, inverse link function, $p=0.38,0.14$ and $0.55, \mathrm{~N}=79,106$ and 100, 
respectively). There was however a tendency for immature birds to show higher $\mathrm{Hg}$ concentrations than non-breeding ones.

\section{DISCUSSION}

The present work is one of the most comprehensive evaluations of POP and trace element burdens in free-living seabirds of known life-history traits, because of the large number of both sampled individuals $(\mathrm{N}=180)$ and targeted contaminants $(\mathrm{N}=33)$. Our results document that the wandering albatross was exposed to a wide range of organic and inorganic contaminants during the breeding period, highlighting the extent of global contamination in the remote Southern Ocean. Recent investigations on physiological and demographic consequences of selected contaminants on the same individuals have revealed that blood POP and $\mathrm{Hg}$ concentrations are related to increased oxidative damage ${ }^{43}$ and to decreased breeding probability and output.

Pattern of contamination and comparison to other species and areas. Previous studies in subantarctic seabirds evaluated legacy-POP concentrations in internal tissues of dead individuals, ${ }^{14-16,66}$ and emerging-POPs (perfluorinated compounds) in blood. ${ }^{17}$ Therefore, no previous data is available for comparing wandering albatross blood concentrations of legacyPOPs to those of neither subantarctic, nor subtropical seabirds from the Southern Hemisphere. Plasma POP concentrations of the wandering albatross were similar to or lower than those of high-Antarctic seabirds. For example, the south polar skua Catharacta maccormicki had threeand 15-fold higher plasma HCB and mirex concentrations, respectively, than the wandering albatross, while median PCB concentrations were comparable. ${ }^{67}$ The snow petrel Pterodroma nivea showed similar OCP, but higher PCB concentrations than wandering albatrosses. ${ }^{68}$ When compared to seabirds from the Northern Hemisphere, wandering albatrosses had overall lower plasma POP concentrations. In particular, two- to 200-fold higher median PCB concentrations have been reported in the plasma of Arctic seabirds (e.g., refs 67 and 69) and North Pacific 
albatrosses. ${ }^{13,32,70}$ Conversely, differences in plasma OCP concentrations between the wandering albatross and Northern Hemisphere seabirds are less pronounced, especially for HCB and mirex. ${ }^{38,69}$ Overall, the pattern of organic contamination in plasma of the wandering albatross is remarkable for three main reasons: (1) the smaller abundance of PCBs over OCPs (Figure 2) with respect to Northern Hemisphere species, which is probably related to the distance to industrial sources; ${ }^{67}$ (2) the lower concentrations of PBDEs than both PCBs and OCPs, as reported in other albatrosses; ${ }^{13}$ and (3) the abundance of HCB, mirex and DDT derivatives, which testifies to their use and emissions in the Southern Hemisphere, ${ }^{71,72}$ including recent DDT application for disease vector control. ${ }^{73}$

With regards to nonessential trace elements, blood $\mathrm{Hg}$ concentrations were remarkably high in the wandering albatross, as previously shown in feathers (e.g., ref 27, 48, and 49) and internal tissues (e.g., ref 74). Similar blood $\mathrm{Hg}$ concentrations have recently been reported in the brown skua Stercorarius lonnbergi from the subantarctic Kerguelen Islands. ${ }^{28}$ Wandering albatrosses had higher blood $\mathrm{Hg}$ concentrations than Antarctic seabirds, such as the south polar skua ${ }^{28}$ and the snow petrel. ${ }^{42}$ Notably, blood $\mathrm{Hg}$ concentrations of wandering albatrosses were comparable to those of the great skua Catharacta skua, ${ }^{39}$ one of the species with the highest blood $\mathrm{Hg}$ concentration in the Northern Hemisphere. On the other hand, blood Cd concentrations were lower than expected, given the importance of squid in the diet of the wandering albatross. ${ }^{75}$ Squid has been recognized to be an important vector for Cd transfer to top predators. ${ }^{19}$ However, similar low Cd concentrations were found in blood of wandering albatrosses at South Georgia, southern Atlantic Ocean. ${ }^{35}$ This result suggests that after assimilation Cd is efficiently transported toward target tissues where it is stored, as proved by high concentrations in liver and kidneys. ${ }^{74,76}$ Low blood concentrations were reported also for $\mathrm{Pb}$, which is consistent with results of Anderson et al. ${ }^{35}$ and likely the consequence of low dietary exposure. Indeed, high blood $\mathrm{Pb}$ concentrations have been reported in procellariiform species feeding in neritic waters 
off Patagonia and Brazil, respectively, thus reflecting the contamination of those coastal waters. ${ }^{77,78}$ With regards to essential elements, blood concentrations had relatively low between-individual variation (Table S4, SI) and were overall within the same range of values as other subantarctic procellariiform seabirds, ${ }^{35,77}$ suggesting that no apparent deficiencies were present in this population.

Effect of lipids and breeding status. Since POPs are strongly lipophilic, their concentrations in living organisms are influenced by lipid dynamics. ${ }^{2}$ Here, plasma POP concentrations were influenced by lipid content, in particular for PCBs. This is consistent with previous works showing that lipid status is more determinant for some compounds, such as low chlorinated PCBs. ${ }^{41,45,46}$ Breeding status implies particular physiological conditions that could also affect blood contaminant concentrations. ${ }^{40,79}$ Again, only plasma PCBs were significantly affected by breeding status, indicating that physiological traits may be more important than extrinsic factors in driving variation for this class of POPs. On the other hand, immature birds had slightly higher blood $\mathrm{Hg}$ concentrations than nonbreeding individuals. It has been hypothesized that immatures moult less frequently than adults, ${ }^{80}$ which would mean that they have fewer opportunities to excrete $\mathrm{Hg}$ into feathers, 49 but there is no conclusive evidence to support this explanation. Other between-individual and between compounds differences in detoxification capabilities can also be responsible for the high variability in the data, especially for POPs. The whole body biological half-life of some POPs in birds can be long (100-400 days for the herring gull Larus argentatus). ${ }^{81}$ There is thus a partial temporal uncoupling between POPs and stable isotope ratios in blood, ${ }^{6}$ which could imply carry-over effects of past exposure over wintering grounds. ${ }^{36}$ Clearly, a better knowledge on the toxicokinetics of contaminants in blood is needed for the complete understanding of between-individual variation in seabird exposure and contaminant burdens. 
Effect of age. Blood concentrations of POPs, $\mathrm{Hg}$ and $\mathrm{Cd}$ were not age-related in breeding wandering albatrosses, despite the large age range (7-47 years) and sample size. The absence of age-dependent variation in contaminant concentrations has already been reported in blood $^{41,49,70,77}$ and feathers ${ }^{82,83}$ of other known-age seabirds, with also some possible decreasing trends being observed. ${ }^{42}$ While some studies show contrasting results for age-related trends of trace elements in seabird internal organs, especially $\mathrm{Cd},{ }^{84,85}$ overall there is no evidence of a clear, significant increase in POP and $\mathrm{Hg}$ concentrations with adult age in any tissue. This pattern could be explained by efficient detoxification mechanisms in seabirds. Indeed, feather excretion is a well-known mechanism for $\mathrm{Hg}$ elimination (e.g., ref 37), which is significant also for organic contaminants (e.g., ref 86). Moreover, POPs can be excreted in preen oil ${ }^{87}$ and undergo biotransformation in internal tissues. 2 This contrasts with results in marine mammals, which have shown clear age dependent increases in adult internal tissues contamination, including blood. ${ }^{88-90}$ Moreover, the absence of confounding age-related variation in contaminant concentrations enhances the value of adult seabirds' blood as a reliable biomonitoring tool of environmental contamination. ${ }^{79,82}$ It must be noted, however, that the present work is a cross-sectional study, which does not necessarily reveal information on the contamination of individuals as they age. ${ }^{91}$ However, similar contaminant concentrations have been reported in seabirds sampled repeatedly in different years. ${ }^{41,70}$ Furthermore, POPs, $\mathrm{Hg}$, and $\mathrm{Cd}$ did not affect mortality in the wandering albatross, ${ }^{44}$ which excludes potential bias from differential survival of the most contaminated individuals.

Effect of feeding habitat and sex during the breeding period. Key findings of the present study are the correlations between blood $\delta^{13} \mathrm{C}$ values and blood OCP and $\mathrm{Hg}$ concentrations (Figure 1). The Southern Ocean is marked by a well-defined latitudinal baseline $\delta_{13} \mathrm{C}$ gradient that is reflected in the tissue of consumers. ${ }^{50,58,92}$ The wide range of blood $\delta_{13} \mathrm{C}$ values thus indicates that wandering albatrosses foraged over a vast latitudinal area during the incubation 
period. Based on blood $\delta^{13} \mathrm{C}$ isoscapes, wandering albatrosses exploited large domains of the Subantarctic and Subtropical Zones. ${ }^{50}$ The inverse relationship between blood $\delta^{13} \mathrm{C}$ values and OCP concentrations (Figure 1a) therefore strongly suggests a latitudinal pattern in OCP transfer to predators, which increased from warm subtropical (high $\delta^{13} \mathrm{C}$ values) to cold subantarctic waters (low $\delta^{13} \mathrm{C}$ values). Conversely, the direct correlation between blood values and $\mathrm{Hg}$ concentrations (Figure 1b) likely indicates the opposite pattern in $\mathrm{Hg}$ transfer to predators, which decreased from warm subtropical (high $\delta^{13} \mathrm{C}$ values) to cold subantarctic (low $\delta 13 \mathrm{C}$ values) waters. Importantly, sexual differences in contaminant exposure were explained by gender specialization in foraging habitats. ${ }^{61,93}$ Indeed, male (vs female) wandering albatrosses had higher exposure to POPs (vs $\mathrm{Hg}$ ) likely because they used more subantarctic (vs subtropical) waters (Figure 1). Gender differences in uptake, metabolism, storage and excretion of organic and inorganic contaminants cannot be excluded, particularly taking into account that a fraction of both POPs and $\mathrm{Hg}$ is eliminated through the egg for females. ${ }^{69,85}$ However, since the wandering albatross is a biennial species laying only one egg at each breeding attempt, ${ }^{94}$ egg transfer alone could hardly explain sexual differences in contaminant concentrations (e.g., refs 2 and 95). Indeed, previous studies in low-fecundity seabird species have shown that sexual differences in contaminant concentrations are not always significant and are in different directions depending on species. ${ }^{2,77,95}$ The observed higher blood concentration of $\mathrm{Cd}$ in females than in males was partially related to feeding habitats (Table 2) and is more difficult to explain. Nevertheless, different proportions of particular prey species (e.g., squids) between males and females could account for this pattern.

Latitudinal variation in POP and Hg transfer to predators. The observed latitudinal pattern in POP transfer to the albatrosses, increasing from warm subtropical to cold subantarctic waters, is consistent with the cold condensation and fractionation theory. The latter predicts that increasing quantities of POPs are deposited in polar environments by repeated air-surface 
exchange and atmospheric transport, with the mixture shifting to more volatile compounds. ${ }^{9}$ Our results thus suggest that OCPs enter readily trophic webs after atmospheric deposition, likely through adsorption on organic matter particles and uptake by phytoplankton. ${ }^{10}$ Global distillation seems thus to significantly affect predators' exposure to OCPs in the Southern Ocean. This was not verified for PCBs, most likely due to the extremely high betweenindividual variation in blood (see second section of the discussion). Increases in both OCP and PCB exposure at high latitudes have already been observed in different species and populations of seabirds from Antarctica ${ }^{71}$ and the Norwegian Arctic, ${ }^{38,96}$ respectively, but we are not aware of previous evidence of such a latitudinal variation within a single seabird population.

Unlike POPs and contrary to our prediction, $\mathrm{Hg}$ transfer to the albatrosses decreased from warm subtropical to cold subantarctic waters. Previously, high concentrations of atmospheric $\mathrm{Hg}$ have been observed close to the Antarctic continent when compared to lower latitudes.97 Moreover, the only biogeochemical investigation on $\mathrm{Hg}$ speciation and distribution in Southern Ocean waters has shown high concentrations of $\mathrm{Me}-\mathrm{Hg}$ in Antarctic rather than subantarctic and subtropical waters. ${ }^{30}$ Methyl-Hg is the bioavailable and most toxic form of $\mathrm{Hg}$ that is readily assimilated by low-trophic level organisms and then biomagnifies up the food web. ${ }^{7}$ The heavy $\mathrm{Hg}$ burden of birds feeding in warm subtropical waters is therefore puzzling. However, a significant higher exposure to $\mathrm{Hg}$ in chicks fed by parents foraging in subtropical rather than subantarctic waters was previously underlined in different oceanic seabird species from the Kerguelen Islands. ${ }^{24} \mathrm{~A}$ similar trend appears also from between-species comparisons. Indeed, Antarctic top predators present lower $\mathrm{Hg}$ concentrations than subantarctic ones (see first section of the discussion). Antarctic food webs are simpler that those found at subtropical latitudes. ${ }^{50,98}$ Since food web structure influences $\mathrm{Hg}$ transfer, ${ }^{99,100}$ the complexity of subtropical food webs could explain the higher $\mathrm{Hg}$ exposure in northern than southern foraging predators of the Southern Ocean. In addition, Hg dynamics within food webs is affected by many other factors, 
such as primary productivity, temperature and solar radiation. ${ }^{8}$ Clearly, our results call for indepth investigations of $\mathrm{Hg}$ speciation and food web dynamics in waters of the Southern Ocean. Despite the presence of several confounding factors, our data documents a clear latitudinal trend in both POP and $\mathrm{Hg}$ transfer to predators in the southern Indian Ocean. Since breeding wandering albatrosses feed all along their foraging trips, their blood isotopic signature integrates prey taken in different water masses, thus diluting $\delta^{13} \mathrm{C}$ values. ${ }^{61}$ Such a "“dilution effect"' reduces differences among individuals, further emphasizing the strength of the habitatrelated contaminant exposure depicted here.

\section{Conflict of interest}

The authors declare that there are no conflicts of interest.

\section{Acknowledgements}

The authors thank A. Jaeger and V. Lecomte for their help in collecting blood samples in the field, A. Jaeger, G. Guillou and P. Richard for stable isotope analysis, M. Brault-Favrou and C. Churlaud for trace element analysis, K. Delord, D. Besson and A. Goutte for data base managing, and Y. Le Bras for helpful suggestions on R coding and data analyses. The present work was supported financially and logistically by the Poitou-Charentes Region through a $\mathrm{PhD}$ grant to A. Carravieri, the Agence Nationale de la Recherche through the programs "POLARTOP" (O. Chastel) and "Investments for the future" (Cluster of Excellence COTE, ANR-10-LABX-45), the Aquitaine Region and the European Union (CPER A2E project and the European Regional Development Fund, FEDER), the Institut Polaire Français Paul Emile Victor (IPEV, program no. 109, H. Weimerskirch) and the Terres Australes et Antarctiques Françaises (TAAF). 


\section{References}

(1) Jones, K. C.; De Voogt, P. Persistent organic pollutants (POPs): State of the science. Environ. Pollut. 1999, $100,209-221$.

(2) Borgå, K.; Fisk, A. T.; Hoekstra, P. F.; Muir, D. C. Biological and chemical factors of importance in the bioaccumulation and trophic transfer of persistent organochlorine contaminants in arctic marine food webs. Environ. Toxicol. Chem. 2004, 23, 2367-2385.

(3) Walker, C. H.; Sibly, R. M.; Hopkin, S. P.; Peakall, D. B. Principles of Ecotoxicology, 4th ed.; CRC Press, 2012.

(4) Wolfe, M. F.; Schwarzbach, S.; Sulaiman, R. A. Effects of mercury on wildlife: A comprehensive review. Environ. Toxicol. Chem. 1998, 17, 146-160.

(5) Donaldson, S. G.; Van Oostdam, J.; Tikhonov, C.; Feeley, M.; Armstrong, B.; Ayotte, P.; Boucher, O.; Bowers, W.; Chan, L.; Dallaire, F.; et al. Environmental contaminants and human health in the Canadian Arctic. Sci. Total Environ. 2010, 408, 5165-5234.

(6) Fisk, A. T.; Hobson, K. A.; Norstrom, R. J. Influence of chemical and biological factors on trophic transfer of persistent organic pollutants in the northwater Polynya marine food web. Environ. Sci. Technol. 2001, 35, $732-738$.

(7) Morel, F. M. M.; Kraepiel, A. M. L.; Amyot, M. The chemical cycle and bioaccumulation of mercury. Annu. Rev. Ecol. Syst. 1998, 29, 543-566.

(8) Fitzgerald, W. F.; Lamborg, C. H.; Hammerschmidt, C. R. Marine biogeochemical cycling of mercury. Chem. Rev. 2007, 107, 641-662.

(9) Wania, F.; Mackay, D. Peer reviewed: Tracking the distribution of persistent organic pollutants. Environ. Sci. Technol. 1996, 30, 390A-396A.

(10) Dachs, J.; Lohmann, R.; Ockenden, W. A.; Méjanelle, L.; Eisenreich, S. J.; Jones, K. C. Oceanic biogeochemical controls on global dynamics of persistent organic pollutants. Environ. Sci. Technol. 2002, 36, 4229-4237.

(11) UNEP. Final Review on Scientific Information on Cadmium; 2010.

(12) Iwata, H.; Tanabe, S.; Sakai, N.; Tatsukawa, R. Distribution of persistent organochlorines in the oceanic air and surface seawater and the role of ocean on their global transport and fate. Environ. Sci. Technol. 1993, 27, 1080-1098.

(13) Harwani, S.; Henry, R. W.; Rhee, A.; Kappes, M. A.; Croll, D. A.; Petreas, M.; Park, J.-S. Legacy and contemporary persistent organic pollutants in North Pacific albatross. Environ. Toxicol. Chem. 2011, 30, $2562-2569$.

(14) Guruge, K. S.; Tanaka, H.; Tanabe, S. Concentration and toxic potential of polychlorinated biphenyl congeners in migratory oceanic birds from the North Pacific and the Southern Ocean. Mar. Environ. Res. 2001, $52,271-288$.

(15) Guruge, K. S.; Watanabe, M.; Tanaka, H.; Tanabe, S. Accumulation status of persistent organochlorines in albatrosses from the North Pacific and the Southern Ocean. Environ. Pollut. 2001, 114, 389-398.

(16) Tanabe, S.; Watanabe, M.; Minh, T. B.; Kunisue, T.; Nakanishi, S.; Ono, H.; Tanaka, H. PCDDs, PCDFs, and coplanar PCBs in albatross from the North Pacific and Southern Oceans: Levels, patterns, and toxicological implications. Environ. Sci. Technol. 2004, 38, 403-413.

(17) Tao, L.; Kannan, K.; Kajiwara, N.; Costa, M. M.; Fillmann, G.; Takahashi, S.; Tanabe, S. Perfluorooctanesulfonate and related fluorochemicals in albatrosses, elephant seals, penguins, and polar skuas from the southern ocean. Environ. Sci. Technol. 2006, 40, 7642-7648. 
(18) Noël, M.; Barrett-Lennard, L.; Guinet, C.; Dangerfield, N.; Ross, P. S. Persistent organic pollutants (POPs) in killer whales (Orcinus orca) from the Crozet Archipelago, southern Indian Ocean. Mar. Environ. Res. 2009, 68, 196-202.

(19) Bustamante, P.; Caurant, F.; Fowler, S. W.; Miramand, P. Cephalopods as a vector for the transfer of cadmium to top marine predators in the north-east Atlantic Ocean. Sci. Total Environ. 1998, 220, 71-80.

(20) Bustamante, P.; Cherel, Y.; Caurant, F.; Miramand, P. Cadmium, copper and zinc in octopuses from Kerguelen Islands, Southern Indian Ocean. Polar Biol. 1998, 19, 264-271.

(21) Bustamante, P.; Bocher, P.; Cherel, Y.; Miramand, P.; Caurant, F. Distribution of trace elements in the tissues of benthic and pelagic fish from the Kerguelen Islands. Sci. Total Environ. 2003, 313, 25-39.

(22) Bocher, P.; Caurant, F.; Miramand, P.; Cherel, Y.; Bustamante, P. Influence of the diet on the bioaccumulation of heavy metals in zooplankton-eating petrels at Kerguelen archipelago, Southern Indian Ocean. Polar Biol. 2003, $26,759-767$.

(23) Scheifler, R.; Gauthier-Clerc, M.; Bohec, C. L.; Crini, N.; Cøeurdassier, M.; Badot, P. M.; Giraudoux, P.; Maho, Y. L. Mercury concentrations in king penguin (Aptenodytes patagonicus) feathers at Crozet Islands (subAntarctic): Temporal trend between 1966-1974 and 2000-2001. Environ. Toxicol. Chem. 2005, 24, 125-128.

(24) Blévin, P.; Carravieri, A.; Jaeger, A.; Chastel, O.; Bustamante, P.; Cherel, Y. Wide range of mercury contamination in chicks of Southern Ocean seabirds. PLoS One 2013, 8, e54508.

(25) Carravieri, A.; Bustamante, P.; Churlaud, C.; Cherel, Y. Penguins as bioindicators of mercury contamination in the Southern Ocean: Birds from the Kerguelen Islands as a case study. Sci. Total Environ. 2013, 454-455, $141-148$.

(26) Carravieri, A.; Bustamante, P.; Churlaud, C.; Fromant, A.; Cherel, Y. Moulting patterns drive withinindividual variations of stable isotopes and mercury in seabird body feathers: Implications for monitoring of the marine environment. Mar. Biol. 2014, 161, 963-968.

(27) Carravieri, A.; Cherel, Y.; Blévin, P.; Brault-Favrou, M.; Chastel, O.; Bustamante, P. Mercury exposure in a large subantarctic avian community. Environ. Pollut. 2014, 190, 51-57.

(28) Goutte, A.; Bustamante, P.; Barbraud, C.; Delord, K.; Weimerskirch, H.; Chastel, O. Demographic responses to mercury exposure in two closely-related Antarctic top predators. Ecology 2013, 95, 1075-1086.

(29) Joiris, C. R.; Overloop, W. PCBs and organochlorine pesticides in phytoplankton and zooplankton in the Indian sector of the Southern Ocean. Antarct. Sci. 1991, 3, 371-377.

(30) Cossa, D.; Heimbürger, L. E.; Lannuzel, D.; Rintoul, S. R.; Butler, E. C. V.; Bowie, A. R.; Averty, B.; Watson, R. J.; Remenyi, T. Mercury in the Southern Ocean. Geochim. Cosmochim. Acta 2011, 75, 4037-4052.

(31) Ramos, R.; González-Solís, J. Trace me if you can: The use of intrinsic biogeochemical markers in marine top predators. Front. Ecol. Environ. 2012, 10, 258-266.

(32) Finkelstein, M.; Keitt, B. S.; Croll, D. A.; Tershy, B.; Jarman, W. M.; Rodriguez-Pastor, S.; Anderson, D. J.; Sievert, P. R.; Smith, D. R. Albatross species demonstrate regional differences in North Pacific marine contamination. Ecol. Appl. 2006, 16, 678-686.

(33) Sanpera, C.; Moreno, R.; Ruiz, X.; Jover, L. Audouin's gull chicks as bioindicators of mercury pollution at different breeding locations in the western Mediterranean. Mar. Pollut. Bull. 2007, 54, 691-696.

(34) Ramos, R.; Ramírez, F.; Jover, L. Trophodynamics of inorganic pollutants in a wide-range feeder: The relevance of dietary inputs and biomagnification in the yellow-legged gull (Larus michahellis). Environ. Pollut. $2013,172,235-242$. 
(35) Anderson, O. R. J.; Phillips, R. A.; Shore, R. F.; McGill, R. A. R.; McDonald, R. A.; Bearhop, S. Element patterns in albatrosses and petrels: Influence of trophic position, foraging range, and prey type. Environ. Pollut. 2010, 158, 98-107.

(36) Leat, E. H. K.; Bourgeon, S.; Magnusdottir, E.; Gabrielsen, G. W.; Grecian, W. J.; Hanssen, S. A.; Ólafsdóttir, K.; Petersen, A.; Phillips, R. A.; Strm, H.; et al. Influence of wintering area on persistent organic pollutants in a breeding migratory seabird. Mar. Ecol.: Prog. Ser. 2013, 491, 277-293.

(37) Bearhop, S.; Ruxton, G. D.; Furness, R. W. Dynamics of mercury in blood and feathers of great skuas. Environ. Toxicol. Chem. 2000, 19, 1638-1643.

(38) Sonne, C.; Rigét, F. F.; Leat, E. H. K.; Bourgeon, S.; Borgå, K.; Strøm, H.; Hanssen, S. A.; Gabrielsen, G. W.; Petersen, A.; Olafsdottir, K.; et al. Organohalogen contaminants and blood plasma clinical-chemical parameters in three colonies of North Atlantic Great skua (Stercorarius skua). Ecotoxicol. Environ. Saf. 2013, 92, $245-251$.

(39) Bearhop, S.; Phillips, R. A.; Thompson, D. R.; Waldron, S.; Furness, R. W. Variability in mercury concentrations of great skuas Catharacta skua: The influence of colony, diet and trophic status inferred from stable isotope signatures. Mar. Ecol.: Prog. Ser. 2000, 195, 261-268.

(40) Hipfner, J. M.; Hobson, K. A.; Elliott, J. E. Ecological factors differentially affect mercury levels in two species of sympatric marine birds of the North Pacific. Sci. Total Environ. 2011, 409, 1328-1335.

(41) Bustnes, J. O.; Bakken, V.; Skaare, J. U.; Erikstad, K. E. Age and accumulation of persistent organochlorines: A study of arctic-breeding glaucous gulls (Larus hyperboreus). Environ. Toxicol. Chem. 2003, 22, 2173-2179.

(42) Tartu, S.; Bustamante, P.; Goutte, A.; Cherel, Y.; Weimerskirch, H.; Bustnes, J. O.; Chastel, O. Age-related mercury contamination and relationship with luteinizing hormone in a long-lived Antarctic bird. PLoS One 2014, 9, e103642.

(43) Costantini, D.; Meillère, A.; Carravieri, A.; Lecomte, V.; Sorci, G.; Faivre, B.; Weimerskirch, H.; Bustamante, P.; Labadie, P.; Budzinski, H.; et al. Oxidative stress in relation to reproduction, contaminants, gender and age in a long-lived seabird. Oecologia 2014, 175, 1107-1116.

(44) Goutte, A.; Barbraud, C.; Meillère, A.; Carravieri, A.; Bustamante, P.; Labadie, P.; Budzinski, H.; Delord, K.; Cherel, Y.; Weimerskirch, H.; et al. Demographic consequences of heavy metals and persistent organic pollutants in a vulnerable long-lived bird, the wandering albatross. Proc. R. Soc. B Biol. Sci. 2014, 281, 20133313.

(45) Henriksen, E. O.; Gabrielsen, G. W.; Skaare, J. U. Validation of the use of blood samples to assess tissue concentrations of organochlorines in glaucous gulls, Larus hyperboreus. Chemosphere 1998, 37, 2627-2643.

(46) Bustnes, J. O.; Skaare, J. U.; Erikstad, K. E.; Bakken, V.; Mehlum, F. Whole blood concentrations of organochlorines as a dose metric for studies of the glaucous gull (Larus hyperboreus). Environ. Toxicol. Chem. 2001, 20, 1046-1052.

(47) Cherel, Y.; Ducatez, S.; Fontaine, C.; Richard, P.; Guinet, C. Stable isotopes reveal the trophic position and mesopelagic fish diet of female southern elephant seals breeding on the Kerguelen Islands. Mar. Ecol.: Prog. Ser. 2008, 370, 239-247.

(48) Anderson, O. R. J.; Phillips, R. A.; McDonald, R. A.; Shore, R. F.; McGill, R. A. R.; Bearhop, S. Influence of trophic position and foraging range on mercury levels within a seabird community. Mar. Ecol.: Prog. Ser. 2009, $375,277-288$.

(49) Tavares, S.; Xavier, J. C.; Phillips, R. A.; Pereira, M. E.; Pardal, M. A. Influence of age, sex and breeding status on mercury accumulation patterns in the wandering albatross Diomedea exulans. Environ. Pollut. 2013, 181, $315-320$.

(50) Jaeger, A.; Lecomte, V. J.; Weimerskirch, H.; Richard, P.; Cherel, Y. Seabird satellite tracking validates the use of latitudinal isoscapes to depict predators' foraging areas in the Southern Ocean. Rapid Commun. Mass Spectrom. 2010, 24, 3456-3460. 
(51) Weimerskirch, H.; Cherel, Y.; Delord, K.; Jaeger, A.; Patrick, S. C.; Riotte-Lambert, L. Lifetime foraging patterns of the wandering albatross: Life on the move! J. Exp. Mar. Biol. Ecol. 2014, 450, 68-78.

(52) Park, Y. H.; Gambéroni, L. Cross-frontal exchange of Antarctic intermediate water and Antarctic bottom water in the Crozet Basin. Deep Sea Res. Part II Top. Stud. Oceanogr. 1997, 44, 963-986.

(53) Weimerskirch, H.; Cherel, Y.; Cuenot-Chaillet, F.; Ridoux, V. Alternative foraging strategies and resource allocation by male and female wandering albatrosses. Ecology 1997, 78, 2051-2063.

(54) Keller, J. M.; Kucklick, J. R.; McClellan-Green, P. D. Organochlorine contaminants in loggerhead sea turtle blood: Extraction techniques and distribution among plasma and red blood cells. Arch. Environ. Contam. Toxicol. 2004, 46, 254-264.

(55) Coeurdassier, M.; Fritsch, C.; Faivre, B.; Crini, N.; Scheifler, R. Partitioning of Cd and Pb in the blood of European blackbirds (Turdus merula) from a smelter contaminated site and use for biomonitoring. Chemosphere 2012, 87, 1368-1373.

(56) Frings, C. S.; Fendley, T. W.; Dunn, R. T.; Queen, C. A. Improved determination of total serum lipids by the sulfo-phosphovanillin reaction. Clin. Chem. 1972, 18, 673-674.

(57) Newsome, S. D.; Martinez del Rio, C.; Bearhop, S.; Phillips, D. L. A niche for isotopic ecology. Front. Ecol. Environ. 2007, 5, 429-436.

(58) Cherel, Y.; Hobson, K. A. Geographical variation in carbon stable isotope signatures of marine predators: A tool to investigate their foraging areas in the Southern Ocean. Mar. Ecol.: Prog. Ser. 2007, 329, 281-287.

(59) Cherel; Fontaine, C.; Richard, P.; Labat, J. P. Isotopic niches and trophic levels of myctophid fishes and their predators in the Southern Ocean. Limnol. Oceanogr. 2010, 55, 324.

(60) Hobson, K. A.; Clark, R. G. Turnover of 13C in cellular and plasma fractions of blood: Implications for nondestructive sampling in avian dietary studies. Auk 1993, 638-641.

(61) Jaeger, A.; Goutte, A.; Lecomte, V. J.; Richard, P.; Chastel, O.; Barbraud, C.; Weimerskirch, H.; Cherel, Y. Age, sex, and breeding status shape a complex foraging pattern in an extremely long-lived seabird. Ecology 2014, $95,2324-2333$.

(62) R Core Team. R: A Language and Environment for Statistical Computing; R Foundation for Statistical Computing: Vienna, Austria, 2012.

(63) Zuur, A. F.; Ieno, E. N.; Elphick, C. S. A protocol for data exploration to avoid common statistical problems. Methods Ecol. Evol. 2010, 1, 3-14.

(64) Burnham, K. P.; Anderson, D. R. Model Selection and Multi-Model Inference: A Practical InformationTheoretic Approach; 2nd ed..; Springer, New York, 2002.

(65) Zuur, A. F.; Ieno, E. N.; Walker, N. Mixed Effects Models and Extensions in Ecology with R; Springer, 2009.

(66) Colabuono, F. I.; Taniguchi, S.; Montone, R. C. Organochlorine contaminants in albatrosses and petrels during migration in South Atlantic Ocean. Chemosphere 2012, 86, 701-708.

(67) Bustnes, J. O.; Tveraa, T.; Henden, J. A.; Varpe, Ø.; Janssen, K.; Skaare, J. U. Organochlorines in Antarctic and Arctic avian top predators: A comparison between the South Polar Skua and two species of northern hemisphere gulls. Environ. Sci. Technol. 2006, 40, 2826-2831.

(68) Tartu, S.; Angelier, F.; Wingfield, J. C.; Bustamante, P.; Labadie, P.; Budzinski, H.; Weimerskirch, H.; Bustnes, J. O.; Chastel, O. Corticosterone, prolactin and egg neglect behavior in relation to mercury and legacy POPs in a long-lived Antarctic bird. Sci. Total Environ. 2015, 505, 180-188. 
(69) Bourgeon, S.; Leat, E. K.; Furness, R. W.; Borgå, K.; Hanssen, S. A.; Bustnes, J. O. Dietary versus maternal sources of organochlorines in top predator seabird chicks: An experimental approach. Environ. Sci. Technol. 2013, $47,5963-5970$.

(70) Auman, H. J.; Ludwig, J. P.; Summer, C. L.; Verbrugge, D. A.; Froese, K. L.; Colborn, T.; Giesy, J. P. PCBs, DDE, DDT, and TCDDEQ in two species of albatross on Sand Island, Midway Atoll, North Pacific Ocean. Environ. Toxicol. Chem. 1997, 16, 498-504.

(71) Van den Brink, N. W. Directed transport of volatile organochlorine pollutants to polar regions: The effect on the contamination pattern of Antarctic seabirds. Sci. Total Environ. 1997, 198, 43-50.

(72) Connell, D. W.; Miller, G.; Anderson, S. Chlorohydrocarbon pesticides in the Australian marine environment after banning in the period from the 1970s to 1980s. Mar. Pollut. Bull. 2002, 45, 78-83.

(73) UNEP. Global status of DDT and Its Alternatives for Use in Vector Control to Prevent Disease; 2008.

(74) Hindell, M. A.; Brothers, N.; Gales, R. Mercury and cadmium concentrations in the tissues of three species of southern albatrosses. Polar Biol. 1999, 22, 102-108.

(75) Cherel, Y.; Weimerskirch, H. Spawning cycle of onychoteuthid squids in the southern Indian Ocean: New information from seabird predators. Mar. Ecol.: Prog. Ser. 1999, 188, 93-104.

(76) Stewart, F. M.; Phillips, R. A.; Bartle, J. A.; Craig, J.; Shooter, D. Influence of phylogeny, diet, moult schedule and sex on heavy metal concentrations in New Zealand Procellariiformes. Mar. Ecol.: Prog. Ser. 1999, 178, 295-305.

(77) González-Solís, J.; Sanpera, C.; Ruiz, X. Metals and selenium as bioindicators of geographic and trophic segregation in giant petrels Macronectes spp. Mar. Ecol.: Prog. Ser. 2002, 244, 257-264.

(78) Carvalho, P. C.; Bugoni, L.; McGill, R. A.; Bianchini, A. Metal and selenium concentrations in blood and feathers of petrels of the genus Procellaria. Environ. Toxicol. Chem. 2013, 32, 1641-1648.

(79) Van den Brink, N. W.; Van Franeker, J. A.; De Ruiter-Dijkman, E. M. Fluctuating concentrations of organochlorine pollutants during a breeding season in two Antarctic seabirds: Adelie penguin and southern fulmar. Environ. Toxicol. Chem. 1998, 17, 702-709.

(80) Weimerskirch, H. Sex-specific differences in molt strategy in relation to breeding in the wandering albatross. Condor 1991, 731-737.

(81) Clark, T. P.; Norstrom, R. J.; Fox, G. A.; Won, H. T. Dynamics of organochlorine compounds in herring gulls (Larus argentatus): II. A two-compartment model and data for ten compounds. Environ. Toxicol. Chem. 1987, 6, 547-559.

(82) Furness, R. W.; Lewis, S. A.; Mills, J. A. Mercury levels in the plumage of red-billed gulls Larus novaehollandiae scopulinus of known sex and age. Environ. Pollut. 1990, 63, 33-39.

(83) Thompson, D. R.; Hamer, K. C.; Furness, R. W. Mercury accumulation in great skuas Catharacta skua of known age and sex, and its effects upon breeding and survival. J. Appl. Ecol. 1991, 672-684.

(84) Stewart, F. M.; Furness, R. W. The influence of age on cadmium concentrations in seabirds. Environ. Monit. Assess. 1998, 50, 159-171.

(85) Agusa, T.; Matsumoto, T.; Ikemoto, T.; Anan, Y.; Kubota, R.; Yasunaga, G.; Kunito, T.; Tanabe, S.; Ogi, H.; Shibata, Y. Body distribution of trace elements in black-tailed gulls from Rishiri Island, Japan: Age-dependent accumulation and transfer to feathers and eggs. Environ. Toxicol. Chem. 2005, 24, 2107-2120.

(86) García-Fernández, A. J.; Espín, S.; Martínez-López, E. Feathers as a biomonitoring tool of polyhalogenated compounds: A review. Environ. Sci. Technol. 2013, 47, 3028-3043. 
(87) Yamashita, R.; Takada, H.; Murakami, M.; Fukuwaka, M.; Watanuki, Y. Evaluation of noninvasive approach for monitoring PCB pollution of seabirds using preen gland oil. Environ. Sci. Technol. 2007, 41, 4901-4906.

(88) Ross, P. S.; Ellis, G. M.; Ikonomou, M. G.; Barrett-Lennard, L. G.; Addison, R. F. High PCB Concentrations in Free-Ranging Pacific Killer Whales, Orcinus orca: Effects of Age, Sex and Dietary Preference. Mar. Pollut. Bull. 2000, 40, 504-515.

(89) Lahaye, V.; Bustamante, P.; Dabin, W.; Van Canneyt, O.; Dhermain, F.; Cesarini, C.; Pierce, G. J.; Caurant, F. New insights from age determination on toxic element accumulation in striped and bottlenose dolphins from Atlantic and Mediterranean waters. Mar. Pollut. Bull. 2006, 52, 1219-1230.

(90) Correa, L.; Castellini, J. M.; Wells, R. S.; O’Hara, T. Distribution of mercury and selenium in blood compartments of bottlenose dolphins (Tursiops truncatus) from Sarasota Bay, Florida. Environ. Toxicol. Chem. 2013, 32, 2441-2448.

(91) Binnington, M. J.; Wania, F. Clarifying relationships between persistent organic pollutant concentrations and age in wildlife biomonitoring: Individuals, cross-sections, and the roles of lifespan and sex. Environ. Toxicol. Chem. 2014, 33, 1415-1426.

(92) Quillfeldt, P.; Masello, J. F.; McGill, R. A.; Adams, M.; Furness, R. W. Moving polewards in winter: A recent change in the migratory strategy of a pelagic seabird? Front. Zool. 2010, 7, 15.

(93) Lecomte, V. J.; Sorci, G.; Cornet, S.; Jaeger, A.; Faivre, B.; Arnoux, E.; Gaillard, M.; Trouvé, C.; Besson, D.; Chastel, O.; et al. Patterns of aging in the long-lived wandering albatross. Proc. Natl. Acad. Sci. U. S. A. 2010 , $107,6370-6375$.

(94) Tickell, W. L. N. The biology of the great albatrosses, Diomedea exulans and Diomedea epomophora. Antarct. Res. Ser. 1968, 12, 1-55.

(95) Robinson, S. A.; Lajeunesse, M. J.; Forbes, M. R. Sex differences in mercury contamination of birds: Testing multiple hypotheses with meta-analysis. Environ. Sci. Technol. 2012, 46, 7094-7101.

(96) Steffen, C.; Borgå, K.; Skaare, J. U.; Bustnes, J. O. The occurrence of organochlorines in marine avian top predators along a latitudinal gradient. Environ. Sci. Technol. 2006, 40, 5139-5146.

(97) Soerensen, A. L.; Skov, H.; Jacob, D. J.; Soerensen, B. T.; Johnson, M. S. Global concentrations of gaseous elemental mercury and reactive gaseous mercury in the marine boundary layer. Environ. Sci. Technol. 2010, 44, $7425-7430$

(98) Corsolini, S. Industrial contaminants in Antarctic biota. J. Chromatogr. A 2009, 1216, 598-612.

(99) Cabana, G.; Rasmussen, J. B. Modelling food chain structure and contaminant bioaccumulation using stable nitrogen isotopes. Nature 1994, 372, 255-257.

(100) Point, D.; Sonke, J. E.; Day, R. D.; Roseneau, D. G.; Hobson, K. A.; Vander Pol, S. S.; Moors, A. J.; Pugh, R. S.; Donard, O. F. X.; Becker, P. R. Methylmercury photodegradation influenced by sea-ice cover in Arctic marine ecosystems. Nat. Geosci. 2011, 4, 188-194. 
Table 1. Model selection for blood $\Sigma_{11} \mathrm{OCPs}, \Sigma_{7} \mathrm{PCBs}, \mathrm{Hg}$ and $\mathrm{Cd}$ concentrations in breeding wandering albatrosses from the Crozet Islands. Models are sorted by increasing $\triangle \mathrm{AIC}_{\mathrm{c}}$ (i.e., decreasing model fit). Models in bold are those retained as the best fit to the data. Abbreviations: $\mathrm{AIC}_{\mathrm{c}}$, Akaike's Information Criteria adjusted for small sample-sizes; $w_{i}, \mathrm{AIC}_{\mathrm{c}}$ weights; Exp. var., explained variation.

\begin{tabular}{|c|c|c|c|c|c|}
\hline models & $k^{b}$ & $\mathrm{AIC}_{\mathrm{c}}$ & $\Delta \mathrm{AIC}_{\mathrm{c}}$ & $w_{i}^{c}$ & $\begin{array}{l}\text { exp. va } \\
(\%)^{a}\end{array}$ \\
\hline \multicolumn{6}{|c|}{$\begin{array}{l}\sum_{\text {F: }} \text { PCBs-GLM, Gamma Distribution, Inverse Link Function, } N=75 \text { (M: } 4 \\
\text { (M) }\end{array}$} \\
\hline lipid & 2 & 452 & 0.00 & 0.29 & 7 \\
\hline lipid + age & 3 & 452 & 0.39 & 0.24 & 7 \\
\hline lipid $+\delta^{13} \mathrm{C}$ & 3 & 453 & 0.68 & 0.20 & 7 \\
\hline lipid + sex & 3 & 453 & 1.05 & 0.17 & 7 \\
\hline age & 2 & 456 & 3.99 & 0.04 & 2 \\
\hline null & 1 & 457 & 4.62 & 0.03 & \\
\hline$\delta^{13} \mathrm{C}$ & 2 & 458 & 6.09 & 0.01 & 0 \\
\hline sex & 2 & 458 & 6.58 & 0.01 & 0 \\
\hline $\begin{array}{l}\text { maximal: } \delta^{13} \mathrm{C}+\text { sex }+ \text { age }+ \text { lipid } \\
+\delta^{13} \mathrm{C}: \text { sex }+\delta^{13} \mathrm{C} \text { :age }\end{array}$ & 7 & 459 & 7.07 & 0.01 & 5 \\
\hline
\end{tabular}

$\sum_{\mathrm{F}}$ OCPs-GLM, Gamma Distribution, Inverse Link Function, $N=75$ ( M: 41,

$\begin{array}{llllll}\delta^{13} \mathrm{C}+\text { sex }+ \text { lipid } & 4 & 503 & 0.00 & 0.29 & 24 \\ \delta^{13} \mathrm{C}+\text { sex + lipid }+\delta^{13} \mathrm{C}: \text { sex } & 5 & 504 & 1.22 & 0.16 & 24 \\ \delta^{13} \mathrm{C}+\text { sex } & 3 & 505 & 1.46 & 0.14 & 21 \\ \delta^{13} \mathrm{C}+\text { sex + lipid + age } & 5 & 505 & 1.81 & 0.12 & 23 \\ \delta^{13} \mathrm{C}+\text { sex + age } & 4 & 506 & 2.61 & 0.08 & 21 \\ \delta^{13} \mathrm{C} & 2 & 506 & 3.03 & 0.06 & 20 \\ \delta^{13} \mathrm{C}+\text { lipid } & 3 & 506 & 3.09 & 0.06 & 22 \\ \text { Sex } & 2 & 507 & 3.82 & 0.04 & 19 \\ \delta^{13} \mathrm{C}+\text { age } & 3 & 507 & 3.83 & 0.04 & 21 \\ \text { maximal: } \delta^{13} \mathrm{C}+\text { sex + age + lipid } & 7 & 509 & 5.74 & 0.02 & 22 \\ \quad+\delta^{13} \mathrm{C}: \text { sex }+\delta^{13} \mathrm{C} \text { :age } & & & & & \\ \text { null } & 1 & 521 & 17.99 & 0.00 & \\ \text { lipid } & 2 & 522 & 19.20 & 0.00 & 0 \\ \text { age } & 2 & 523 & 20.15 & 0.00 & 0 \\ \mathrm{Hg}-\mathrm{LM}, N=95(\mathrm{M}: 50, \mathrm{~F}: 45) & & & & & \\ \delta^{13} \mathrm{C}+\text { sex }+\delta^{13} \mathrm{C}: \text { sex } & 4 & 1784 & 0.00 & 0.59 & 53 \\ \delta^{13} \mathrm{C}+\text { sex }+ \text { age }+\delta^{13} \mathrm{C}: \text { sex } & 5 & 1786 & 2.27 & 0.19 & 53 \\ \text { maximal: } \delta^{13} \mathrm{C}+\text { sex }+ \text { age }+ & 6 & 1788 & 4.35 & 0.07 & 53 \\ \delta^{13} \mathrm{C}: \operatorname{sex}+\delta^{13} \mathrm{C}: \text { age } & & & & & \\ \delta^{13} \mathrm{C} & 2 & 1789 & 4.70 & 0.06 & 50\end{array}$

\begin{tabular}{|c|c|c|c|c|c|}
\hline models & $k^{b}$ & $\mathrm{AIC}_{\mathrm{c}}$ & $\Delta \mathrm{AIC}_{\mathrm{c}}$ & $w_{i}^{c}$ & $\begin{array}{l}\text { exp. var. } \\
(\%)^{d}\end{array}$ \\
\hline \multicolumn{6}{|l|}{ Hg-LM, $N=95$ (M: 50, F: 45) } \\
\hline$\delta^{13} \mathrm{C}+\operatorname{sex}$ & 3 & 1789 & 5.21 & 0.04 & 50 \\
\hline$\delta^{13} \mathrm{C}+$ age & 3 & 1790 & 6.42 & 0.02 & 50 \\
\hline$\delta^{13} \mathrm{C}+$ sex + age & 4 & 1791 & 7.03 & 0.02 & 50 \\
\hline$\delta^{13} \mathrm{C}+$ age $+\delta^{13} \mathrm{C}$ :age & 4 & 1792 & 7.74 & 0.01 & 50 \\
\hline$\delta^{13} \mathrm{C}+$ sex + age $+\delta^{13} \mathrm{C}$ :age & 5 & 1793 & 8.58 & 0.00 & 50 \\
\hline sex & 2 & 1820 & 36.21 & 0.00 & 30 \\
\hline sex + age & 3 & 1822 & 38.39 & 0.00 & 29 \\
\hline null & 1 & 1853 & 69.25 & 0.00 & \\
\hline age & 2 & 1855 & 71.22 & 0.00 & 0 \\
\hline \multicolumn{6}{|c|}{ Cd-GLM, Gamma Distribution, Inverse Link Function, $N=93$ (M: 49, F: 44) } \\
\hline$\delta^{13} \mathrm{C}+\operatorname{sex}$ & 3 & 890 & 0.00 & 0.33 & 7 \\
\hline Sex & 2 & 891 & 0.94 & 0.21 & 5 \\
\hline$\delta^{13} \mathrm{C}+$ sex + age & 4 & 892 & 1.99 & 0.12 & 6 \\
\hline$\delta^{13} \mathrm{C}+\operatorname{sex}+\delta^{13} \mathrm{C}: \operatorname{sex}$ & 4 & 892 & 2.17 & 0.11 & 6 \\
\hline sex + age & 3 & 893 & 2.96 & 0.07 & 4 \\
\hline$\delta^{13} \mathrm{C}+$ sex + age $+\delta^{13} \mathrm{C}:$ age & 5 & 893 & 3.84 & 0.05 & 4 \\
\hline$\delta^{13} \mathrm{C}+$ sex + age $+\delta^{13} \mathrm{C}:$ sex & 5 & 894 & 4.11 & 0.04 & 4 \\
\hline null & 1 & 895 & 4.99 & 0.03 & \\
\hline $\begin{array}{l}\underset{\delta^{13} \mathrm{C}: \mathrm{sex}}{\operatorname{maximal}} \delta^{13} \mathrm{C}+\text { sex }+ \text { age }+ \\
\delta^{13} \mathrm{C}: \text { age }\end{array}$ & 7 & 896 & 6.12 & 0.02 & 5 \\
\hline age & 2 & 896 & 6.82 & 0.01 & 0 \\
\hline$\delta^{13} \mathrm{C}$ & 2 & 896 & 6.89 & 0.01 & 0 \\
\hline$\delta^{13} \mathrm{C}+$ age & 3 & 898 & 8.83 & 0.00 & 0 \\
\hline$\delta^{13} \mathrm{C}+$ age $+\delta^{13} \mathrm{C}$ :age & 4 & 899 & 10.28 & 0.00 & 0 \\
\hline \multicolumn{6}{|c|}{$\begin{array}{l}{ }^{a} \text { Models are sorted by increasing } \triangle \mathrm{AIC}_{\mathrm{c}} \text { (i.e., decreasing model fit). } \\
\text { Abbreviations: AIC }{ }_{o} \text { Akaike's Information Criteria adjusted for small } \\
\text { sample-sizes; } w_{\mathrm{v}} \text { Akaike's weights; Exp. var., explained variation. } \\
{ }^{b} \text { Number of parameters. 'Weight of evidence interpreted as a } \\
\text { proportion. Weights across all models sum to } 1.00 \text {. 'Explained } \\
\text { variation calculated from deviance or variance for GLM and LM, } \\
\text { respectively, and adjusted depending on } k \text { and N. }\end{array}$} \\
\hline
\end{tabular}

aModels are sorted by increasing $\triangle \mathrm{AIC}$ (i.e., decreasing model fit). Abbreviations: AIC c, Akaike's Information Criteria adjusted for small sample-sizes; wi, Akaike's weights; Exp. var., explained variation.

bNumber of parameters.

cWeight of evidence interpreted as a proportion. Weights across all models sum to 1.00 .

dExplained variation calculated from deviance or variance for GLM and LM, respectively, and adjusted depending on $\mathrm{k}$ and $\mathrm{N}$. 
Table 2. Sum of Akaike's weights across all models of each tested explanatory variable for blood $\Sigma_{7} \mathrm{PCBs}, \Sigma_{11} \mathrm{OCPs}, \mathrm{Hg}$, and Cd concentrations in breeding wandering albatrosses from the Crozet Islands.

\begin{tabular}{ccccc} 
& \multicolumn{4}{c}{ sum of Akaike's weights across all models } \\
\cline { 2 - 5 } explanatory variables & $\sum_{7}$ PCBs & $\sum_{11}$ OCPs & Hg & Cd \\
age & 0.29 & 0.26 & 0.31 & 0.31 \\
lipid & 0.91 & 0.65 & & \\
sex & 0.19 & 0.85 & 0.91 & 0.95 \\
$\delta^{13} \mathrm{C}$ & 0.22 & 0.97 & 1 & 0.68 \\
\hline
\end{tabular}



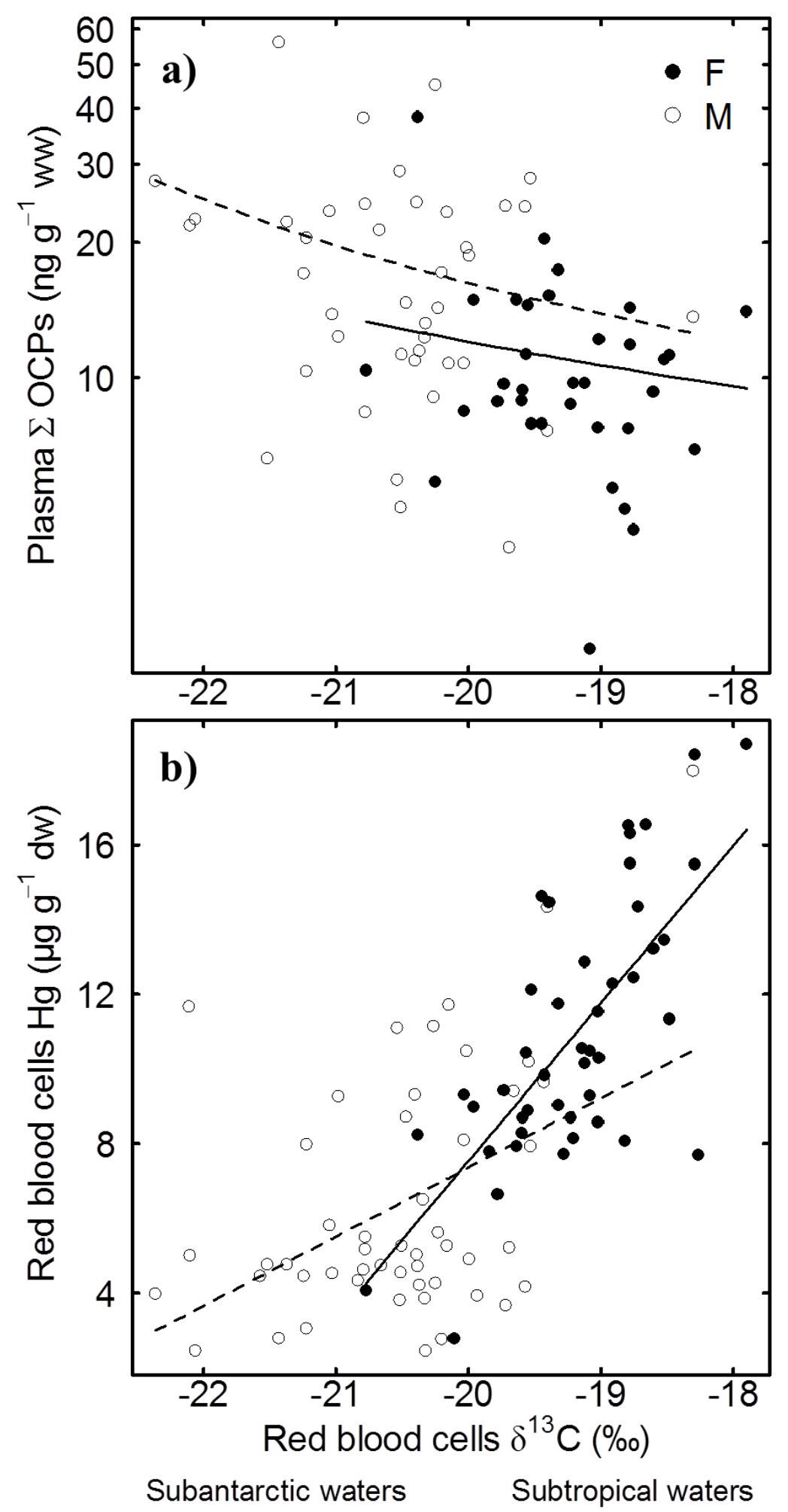

Figure 1. a) OCPs concentrations decrease whereas b) $\mathrm{Hg}$ concentrations increase with increasing latitude of foraging habitats in blood of breeding wandering albatrosses from the Crozet Islands. 

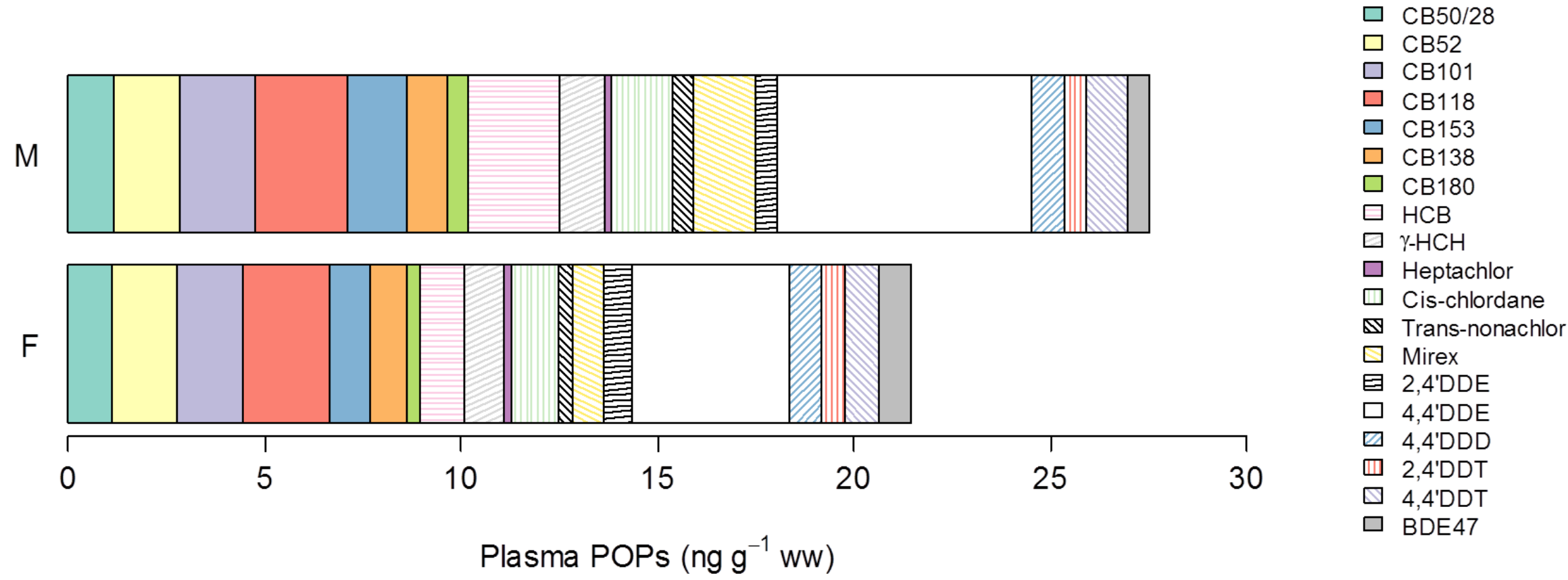

Figure 2. Stacked bar plot of POPs in plasma of male and female wandering albatrosses from the Crozet Islands. Values correspond to median concentrations. 


\section{Appendix - Supplementary Information}

\section{Persistent organic pollutants (POPs) and trace element analysis}

POPs were measured in albatross plasma at the laboratory EPOC-LPTC, Bordeaux, France, (N $=128,100 \mu \mathrm{l}$ aliquots). Targeted compounds included seven polychlorinated biphenyls (PCBs: CB-28/50, -52, -101, -118, -138, -153 and -180), 11 organochlorine pesticides (OCPs: HCB, $\gamma$ $\mathrm{HCH}$, heptachlor, 2,4' DDE, cis-chlordane, 4,4' DDE, trans-nonachlor, 4,4' DDD, 2,4' DDT, 4,4' DDT, mirex) and one polybrominated diphenyl ether (PBDE: BDE 47). Internal standards (CB-30, -103, -155, -198 for PCBs, p,p'-DDT-d8 for OCPs and F-BDE-47 for BDE 47, $1 \mathrm{ng}$ each) were added to each sample. Standards were provided by either Dr Ehrenstorfer GmbH or Cambridge Isotope Laboratory (via Cluzeau Info Labo, Sainte-Foy-La-Grande, France). POPs were extracted with $1 \mathrm{~mL}$ of pentane/dichloromethane (90/10; v/v); after centrifugation (2000 $\mathrm{rpm}, 2 \mathrm{~min}$ at $4^{\circ} \mathrm{C}$ ), the organic layer was collected and the operation was repeated. Both extracts were combined and purified on an acid silica gel column $\left(40 \% \mathrm{H}_{2} \mathrm{SO}_{4}\right)$. After extract loading, analytes were eluted with 3 x $5 \mathrm{~mL}$ of pentane/dichloromethane (90/10; v/v). The soobtained extract was then concentrated using a RapidVap vacuum evaporation system from Labconco (Kansas City, MO, USA) to a volume of $1 \mathrm{~mL}$; it was then further concentrated under a gentle stream of nitrogen $\left(40^{\circ} \mathrm{C}\right)$ after addition of $100 \mu \mathrm{L}$ of isooctane as solvent keeper. A syringe standard (octachloronaphtalene, $1 \mathrm{ng}$ ) was finally added to quantify internal standards and to assess their recovery rate for each sample (68-108\%). Final extracts were analysed by gas chromatography coupled with electron capture detection (GC-ECD) as described in Tapie et al. (2011). CB-28 and -50 co-eluted in all samples. Quality control consisted in the analysis of procedural blanks (clean and empty glass tubes treated like a sample, one run for 8 samples). Chicken plasma samples (Sigma-Aldrich, St Quentin Fallavier, France) spiked at $3 \mathrm{ng} \mathrm{g}^{-1}$ were analysed in parallel to the samples; the recovery rates of PCBs and OCPs were in the range 77$103 \%$ with coefficients of variation lower than $17 \%(\mathrm{~N}=5)$, except for CB $52(22 \%)$ and mirex (29\%). POPs concentrations were blank corrected and the detection limit (LoD) was set at two times the mean blank value; for analytes that were not detected in blanks, LoD was determined as the concentration with a signal to noise ratio of 3. Overall, LoDs ranged from 0.09 to 0.76 $\mathrm{ng} \mathrm{g}^{-1}$ wet weight.

Trace elements were measured on lyophilized red blood cells at the laboratory LIENSs, La Rochelle, France. Total mercury $(\mathrm{Hg})$ was quantified with an Altec AMA 254 spectrophotometer $(\mathrm{N}=169$, aliquots mass: 5-10 mg dry weight, dw). All analyses were 
repeated in duplicate-triplicate until having a relative standard deviation $<5 \%$ for each individual. Accuracy was checked using a certified reference material (CRM, Tort-2 Lobster Hepatopancreas, NRC, Canada; certified Hg concentration: $0.27 \pm 0.06 \mu \mathrm{g} \mathrm{g}^{-1} \mathrm{dw}$ ). Our measured values were $0.24 \pm 0.02 \mu \mathrm{g} \mathrm{g}^{-1} \mathrm{dw}, \mathrm{N}=31$. Mass of the $\mathrm{CRM}$ was adjusted to represent the same amount of $\mathrm{Hg}$ introduced in the AMA compared to the one in blood samples. Blanks were analysed at the beginning of each set of samples and the detection limit of the method was $0.005 \mu \mathrm{g} \mathrm{g}^{-1} \mathrm{dw}$. Arsenic (As), chromium $(\mathrm{Cr})$, copper $(\mathrm{Cu})$, iron $(\mathrm{Fe})$, manganese $(\mathrm{Mn})$, nickel (Ni), selenium (Se) and zinc (Zn) were analysed using a Varian Vista-Pro ICP-OES and silver $(\mathrm{Ag})$, cadmium $(\mathrm{Cd})$, cobalt $(\mathrm{Co})$, lead $(\mathrm{Pb})$ and vanadium $(\mathrm{V})$ using a Series II Thermo Fisher Scientific ICP-MS ( $\mathrm{N}=165$, aliquots mass: 20-200 mg dw). Lyophilised red blood cells were mineralized before analysis. Measurement quality was assessed by CRMs (Tort-2 Lobster Hepatopancreas and Dolt-4 Dogfish Liver, both NRC, Canada), which were treated and analysed in the same way as the samples. Results were in line with the certified values, and the standard deviations were low, proving good repeatability of the method. Elements recovery of standard reference materials ranged from $84 \%$ to $119 \%$. For each set of analyses, blanks were included in each analytical batch. The detection limits $\left(\mu \mathrm{g} \mathrm{g}^{-1} \mathrm{dw}\right)$ were $0.015(\mathrm{Cd}), 0.017(\mathrm{Ag})$, $0.02(\mathrm{Cr}, \mathrm{Co}, \mathrm{Pb}), 0.03(\mathrm{Ni}), 0.08(\mathrm{Mn}), 0.1$ (Cu, Se), $0.2(\mathrm{As}), 0.3(\mathrm{~V})$ and 3.3 (Fe and $\mathrm{Zn}$ ).

\section{Effect of heparin on red blood cell mercury concentrations}

The effect of heparin on red blood cell $\mathrm{Hg}$ concentrations was tested on a domestic pigeon Columba livia domestica by sampling blood using heparinized and non-heparinized syringes. Heparinized and non-heparinized samples had identical red blood cells $\mathrm{Hg}$ concentrations $\left(0.006 \pm 0.001\right.$ and $0.006 \pm 0.002 \mu \mathrm{g} \mathrm{g}^{-1} \mathrm{dw}$, respectively, $\mathrm{n}=4$ in duplicate, Wilcoxon test, $\mathrm{W}$ $=9, \mathrm{p}=0.886$ ).

\section{Stable isotope analyses}

The relative abundance of stable isotopes was determined in red blood cells with a continuous flow mass spectrometer (Thermo Scientific Delta V Advantage) coupled to an elemental analyser (Thermo Scientific Flash EA 1112) $(\mathrm{N}=158$, aliquots mass: $~ 0.3 \mathrm{mg}$ ). Results are in the usual $\delta$ notation relative to Vienna PeeDee Belemnite and atmospheric $\mathrm{N}_{2}$ for $\delta^{13} \mathrm{C}$ and $\delta^{15} \mathrm{~N}$, respectively. Replicate measurements of internal laboratory standards (acetanilide) indicate measurement errors $<0.15 \%$ for both $\delta^{13} \mathrm{C}$ and $\delta^{15} \mathrm{~N}$ values. Results are given in \%o as means \pm SD. 


\section{References}

Tapie, N.; Menach, K. L.; Pasquaud, S.; Elie, P.; Devier, M. H.; Budzinski, H. PBDE and PCB contamination of eels from the Gironde estuary: from glass eels to silver eels. Chemosphere 2011, 83, 175-185. 
Table S1. Limit of detection (LoD) and of quantification (LoQ) in $\mathrm{ng} \mathrm{g}^{-1} \mathrm{ww}$ for the targeted persistent organic pollutants.

\begin{tabular}{lcccccccc}
\hline & Session $^{1}$ & CB-28/50 & CB-52 & CB-101 & CB-118 & CB-153 & CB-138 & CB-180 \\
& & & & & & & & \\
LoD & 1 & 0.1 & 0.1 & 0.1 & 0.2 & 0.1 & 0.1 & 0.02 \\
LoQ & & 0.2 & 0.4 & 0.4 & 0.7 & 0.3 & 0.2 & 0.08 \\
LoD & 2 & 0.1 & 0.8 & 0.6 & 0.5 & 0.3 & 0.2 & 0.01 \\
LoQ & & 0.4 & 2.5 & 1.9 & 1.7 & 0.9 & 0.8 & 0.03 \\
\hline
\end{tabular}

\begin{tabular}{|c|c|c|c|c|c|c|c|c|c|c|c|c|c|}
\hline & Session $^{1}$ & HCB & $\gamma-\mathrm{HCH}$ & Heptachlor & 2,4-DDE & 4,4-DDE & $\begin{array}{c}\text { Cis- } \\
\text { chlordane }\end{array}$ & $\begin{array}{c}\text { Trans- } \\
\text { nonachlor }\end{array}$ & 4,4'-DDD & $\begin{array}{l}\text { 2,4'- } \\
\text { DDT }\end{array}$ & $\begin{array}{l}\text { 4,4'- } \\
\text { DDT }\end{array}$ & Mirex & $\begin{array}{c}\text { BDE- } \\
47\end{array}$ \\
\hline LoD & 1 & 0.03 & 0.13 & 0.03 & 0.09 & 0.05 & 0.07 & 0.04 & 0.05 & 0.04 & 0.04 & 0.05 & 0.05 \\
\hline LoQ & & 0.09 & 0.44 & 0.10 & 0.31 & 0.16 & 0.23 & 0.15 & 0.16 & 0.13 & 0.13 & 0.16 & 0.16 \\
\hline LoD & 2 & 0.17 & 0.04 & 0.05 & 0.15 & 0.15 & 0.15 & 0.15 & 0.15 & 0.01 & 0.05 & 0.05 & 0.03 \\
\hline LoQ & & 0.57 & 0.13 & 0.17 & 0.49 & 0.49 & 0.49 & 0.49 & 0.49 & 0.03 & 0.16 & 0.17 & 0.09 \\
\hline
\end{tabular}

\footnotetext{
${ }^{1}$ POPs concentrations were analysed in two sessions, with LoD and LoQ being calculated from the mean blank of the relative session.
} 
Table S2. Trace elements concentrations $\left(\mu \mathrm{g} \mathrm{g}^{-1} \mathrm{dw}\right.$ ) and stable isotope ratios (\%) of carbon $\left(\delta^{13} \mathrm{C}\right)$ and nitrogen $\left(\delta^{15} \mathrm{~N}\right)$ in red blood cells of the wandering albatross from Crozet Islands.
$>\mathrm{LoQ}$
$\mathrm{N}$
$(\%)$
Median
Mean \pm SD
Min - Max
$\mathrm{CV}(\%)$

Non-essential trace elements

$\begin{array}{lcccccc}\text { Ag } & 165 / 165 & 100 & 0.3 & 0.9 \pm 1.7 & 0.1-9.4 & 189 \\ \mathbf{C d} & 143 / 165 & 87 & 0.06 & 0.07 \pm 0.03 & <\text { LoQ }-0.22 & 43 \\ \mathbf{H g} & 169 / 169 & 100 & 7.5 & 7.7 \pm 3.6 & 2.0-18.7 & 47 \\ \mathbf{P b} & 60 / 165 & 36 & 0.04 & 0.06 \pm 0.06 & <\text { LoQ }-0.43 & 95\end{array}$

Essential trace elements

$80 / 165$

$\begin{array}{ccc}\text { As } & \text { 80/165 } & 48 \\ & \text { All }<\end{array}$

0.6

$0.7 \pm 0.4$

$<\mathrm{LoQ}-2.3$

53

Co

LoQ

0

Cr 64/165 39

$\mathrm{Cu} \quad 165 / 165 \quad 100$

Fe $165 / 165 \quad 100$

0.2

$0.2 \pm 0.2$

$<$ LoQ -0.9

90

1.1

$0.5-4.1$

$879-5100$

27

2347

$2326 \pm 345$

15

All <

Mn LoQ 0

$\begin{array}{lcc}\text { Ni } & 21 / 165 & 13 \\ \text { Se } & 165 / 165 & 100\end{array}$

0 -

Zn $165 / 165 \quad 100$

0.1

$0.1 \pm 0.1$

$<\mathrm{LoQ}-0.5$

$-$

$\begin{array}{lll} & \text { All }< & \\ \text { V } & \text { LoQ } & 0\end{array}$

Stable isotope ratios

$\delta^{\mathbf{1 3}} \mathbf{C} \quad 158 / 158$

$\delta^{\mathbf{1 5}} \mathbf{N} \quad 158 / 158$

100

100
100

-19.8
13.8

$77.1 \pm 33.0$

$13.6-216$

79

73.4

$22.2 \pm 3.9$

$8.5-41.4$

43

21.9

$22.2 \pm 3.9$

18

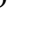


Table S3. Plasma lipid content and persistent organic pollutants concentrations ( $\mathrm{ng} \mathrm{g}^{-1}$ ) relative to the wet and lipid weight (ww and lw, respectively) of the wandering albatross from the Crozet Islands (samples above the limit of quantification, LoQ).

\begin{tabular}{|c|c|c|c|c|c|c|c|c|c|}
\hline \multirow{3}{*}{ Lipid (\%) } & \multirow{3}{*}{$\begin{array}{c}\mathrm{N} \\
128 / 128\end{array}$} & \multirow{3}{*}{$\begin{array}{c}>\operatorname{LoQ}(\%) \\
100\end{array}$} & \multicolumn{2}{|c|}{ Mean \pm SD } & \multicolumn{2}{|c|}{ Median } & \multicolumn{2}{|c|}{ Min - Max } & \multirow{2}{*}{$\begin{array}{c}\mathrm{CV}(\%) \\
21\end{array}$} \\
\hline & & & \multicolumn{2}{|c|}{$0.62 \pm 0.13$} & \multicolumn{2}{|c|}{0.60} & \multicolumn{2}{|c|}{$0.37-1.03$} & \\
\hline & & & ww & $1 \mathrm{w}$ & Ww & $\mathrm{lw}$ & ww & lw & ww \\
\hline CB 50/28 & $64 / 128$ & 50 & $1.8 \pm 2.7$ & $282 \pm 421$ & 1.2 & 173 & $<\mathrm{LoQ}-19.7$ & $<\mathrm{LoQ}-2983$ & 148 \\
\hline CB 52 & $86 / 128$ & 67 & $7.7 \pm 22.7$ & $1191 \pm 3544$ & 1.7 & 271 & $<\operatorname{LoQ}-192.2$ & $<\operatorname{LoQ}-29120$ & 296 \\
\hline CB 101 & $70 / 128$ & 55 & $12.6 \pm 25.9$ & $1926 \pm 3979$ & 1.9 & 289 & $<\operatorname{LoQ}-174.7$ & $<\mathrm{LoQ}-26470$ & 206 \\
\hline CB 118 & $82 / 128$ & 64 & $13.0 \pm 26.5$ & $2011 \pm 4101$ & 2.3 & 363 & $<\operatorname{LoQ}-176.0$ & $<\operatorname{LoQ}-26660$ & 203 \\
\hline CB 153 & $112 / 128$ & 88 & $4.6 \pm 8.5$ & $715 \pm 1319$ & 1.4 & 262 & $<\mathrm{LoQ}-49.3$ & $<\mathrm{LoQ}-7465$ & 187 \\
\hline CB 138 & $100 / 128$ & 78 & $5.6 \pm 11.5$ & $858 \pm 1777$ & 1.0 & 174 & $<\mathrm{LoQ}-58.9$ & $<\mathrm{LoQ}-8945$ & 207 \\
\hline CB 180 & $128 / 128$ & 100 & $0.8 \pm 0.9$ & $127 \pm 146$ & 0.5 & 75 & $0.10-5.7$ & $15-867$ & 119 \\
\hline$\Sigma_{7}$ PCBs & & & $30.4 \pm 79.6$ & $4705 \pm 12282$ & 5.7 & 1008 & $0.1-676.4$ & $15-102500$ & 261 \\
\hline HCB & $125 / 128$ & 98 & $2.2 \pm 1.5$ & $357 \pm 257$ & 1.8 & 283 & $<\mathrm{LoQ}-10.0$ & $<\operatorname{LoQ}-1458$ & 72 \\
\hline$\gamma-\mathrm{HCH}$ & $59 / 128$ & 46 & $1.7 \pm 0.6$ & $206 \pm 105$ & 1.1 & 197 & $<\mathrm{LoQ}-3.6$ & $<\operatorname{LoQ}-630$ & 50 \\
\hline Heptachlor & $37 / 128$ & 29 & $0.4 \pm 0.8$ & $71 \pm 132$ & 0.2 & 33 & $<\operatorname{LoQ}-4.7$ & $<\mathrm{LoQ}-712$ & 194 \\
\hline Cis-chlordane & $77 / 128$ & 60 & $1.5 \pm 1.0$ & $250 \pm 166$ & 1.4 & 214 & $<\operatorname{LoQ}-5.2$ & $<\mathrm{LoQ}-806$ & 66 \\
\hline Trans- & & & & & & & & & \\
\hline nonachlor & $99 / 128$ & 77 & $0.5 \pm 0.3$ & $83 \pm 45$ & 0.5 & 74 & $<\mathrm{LoQ}-1.6$ & $<\mathrm{LoQ}-269$ & 52 \\
\hline Mirex & $122 / 128$ & 95 & $1.4 \pm 1.1$ & $234 \pm 180$ & 1.1 & 173 & $<\operatorname{LoQ}-6.2$ & $<\mathrm{LoQ}-946$ & 77 \\
\hline 2-4' DDT & $84 / 128$ & 66 & $1.1 \pm 1.4$ & $176 \pm 221$ & 0.6 & 89 & $<\mathrm{LoQ}-6.8$ & $<\mathrm{LoQ}-1257$ & 123 \\
\hline 4-4' DDT & $78 / 128$ & 61 & $1.4 \pm 1.6$ & $228 \pm 250$ & 1.0 & 154 & $<\operatorname{LoQ}-9.3$ & $<\mathrm{LoQ}-1615$ & 108 \\
\hline 2-4' DDE & $55 / 128$ & 43 & $0.8 \pm 0.5$ & $129 \pm 90$ & 0.6 & 100 & $<\operatorname{LoQ}-2.8$ & $<$ LoQ - 528 & 65 \\
\hline 4-4' DDE & $125 / 128$ & 98 & $6.8 \pm 5.0$ & $1138 \pm 838$ & 5.4 & 946 & $<\mathrm{LoQ}-28.9$ & $<\mathrm{LoQ}-4846$ & 73 \\
\hline 4-4' DDD & $102 / 128$ & 80 & $0.9 \pm 0.5$ & $154 \pm 82$ & 0.8 & 135 & $<$ LoQ -2.6 & $<$ LoQ -560 & 50 \\
\hline$\Sigma_{10}$ OCPs & & & $14.7 \pm 9.0$ & $2445 \pm 1505$ & 12.2 & 2089 & $1.3-56.0$ & $263-7583$ & 61 \\
\hline BDE 47 & $23 / 128$ & 18 & $0.6 \pm 0.4$ & $97 \pm 64$ & 0.6 & 94.6 & $<\mathrm{LoQ}-1.9$ & $<\mathrm{LoQ}-322$ & 66 \\
\hline$\Sigma_{18}$ POPs & & & $45.3 \pm 81.1$ & $7167 \pm 12475$ & 20.1 & 3253 & $2.3-696.2$ & $448-105500$ & 179 \\
\hline
\end{tabular}


Table S4. Blood persistent organic pollutants and trace elements loadings on the three axes selected from the principal component analysis of wandering albatrosses from the Crozet Islands.

\begin{tabular}{|ccccccccccccccccccccccc}
\hline Axis & CB-153 & CB-138 & CB-180 & HCB & Trans-nonachlor & $4,4^{\prime}$ DDE & $4,4^{\prime}$ DDD & Mirex & Hg & Fe & Cu & Zn & Se & Ag & Cd \\
PC1 & $-0,09$ & $-0,12$ & $-0,04$ & 0,41 & 0,43 & 0,45 & 0,39 & 0,47 & $-0,14$ & 0,04 & $-0,01$ & $-0,01$ & 0,06 & 0,05 & $-0,12$ \\
PC2 & $-0,52$ & $-0,50$ & $-0,51$ & $-0,21$ & 0,11 & $-0,09$ & $-0,03$ & $-0,04$ & 0,24 & 0,10 & 0,16 & 0,14 & 0,15 & 0,09 & 0,08 \\
PC3 & 0,17 & 0,19 & 0,16 & 0,09 & $-0,03$ & 0,10 & 0,02 & $-0,01$ & 0,12 & 0,49 & 0,46 & 0,39 & 0,30 & 0,07 & 0,42 \\
\end{tabular}


Fig. 1. Circle of correlations with the two first axes (PC1 and PC2) of a principal component analysis of log-transformed, standardized persistent organic pollutants and trace elements in blood of the wandering albatross from the Crozet Islands.

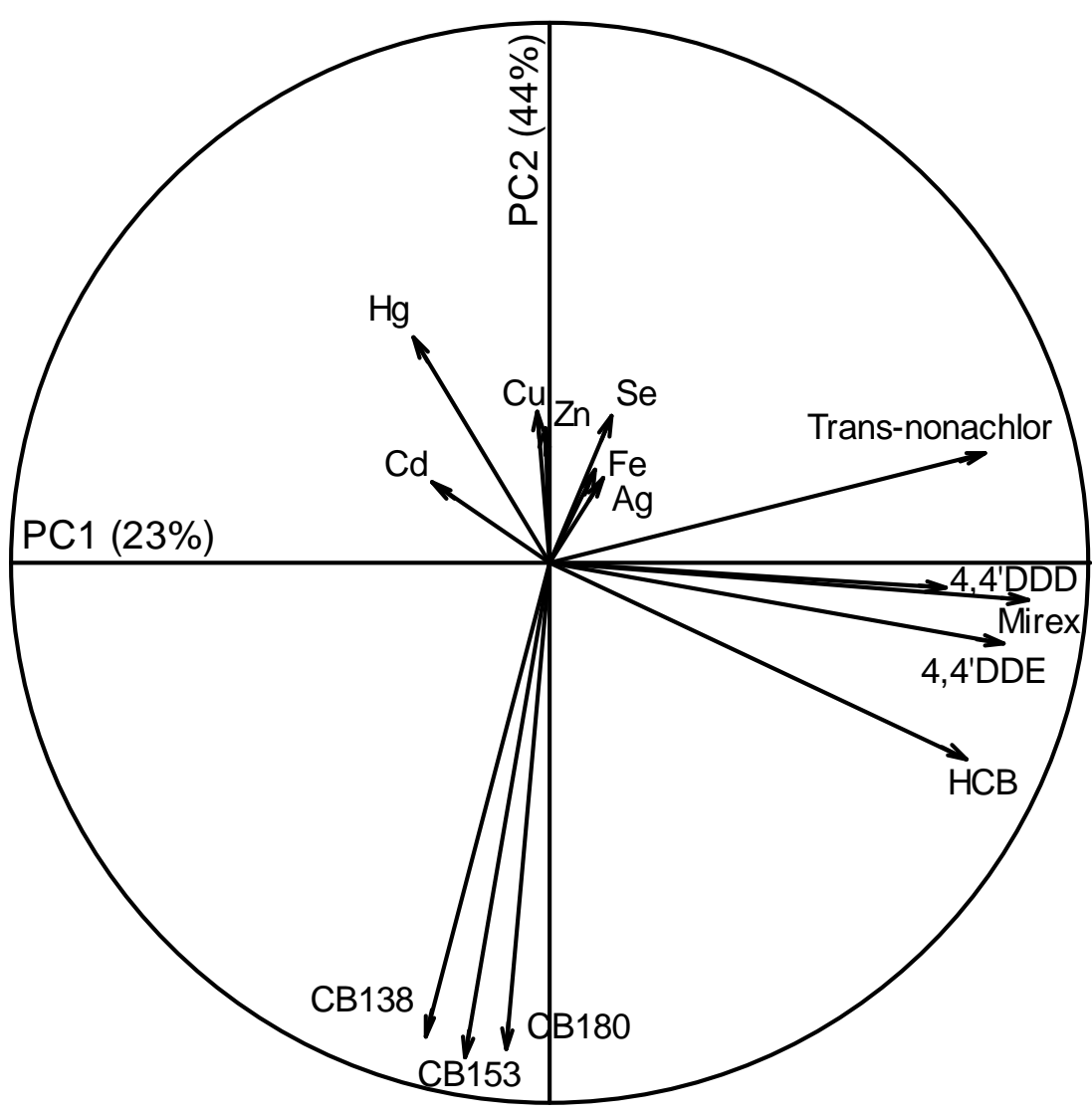


Fig. 2. PCBs concentrations increase with lipid content in blood of breeding wandering albatrosses from the Crozet Islands.

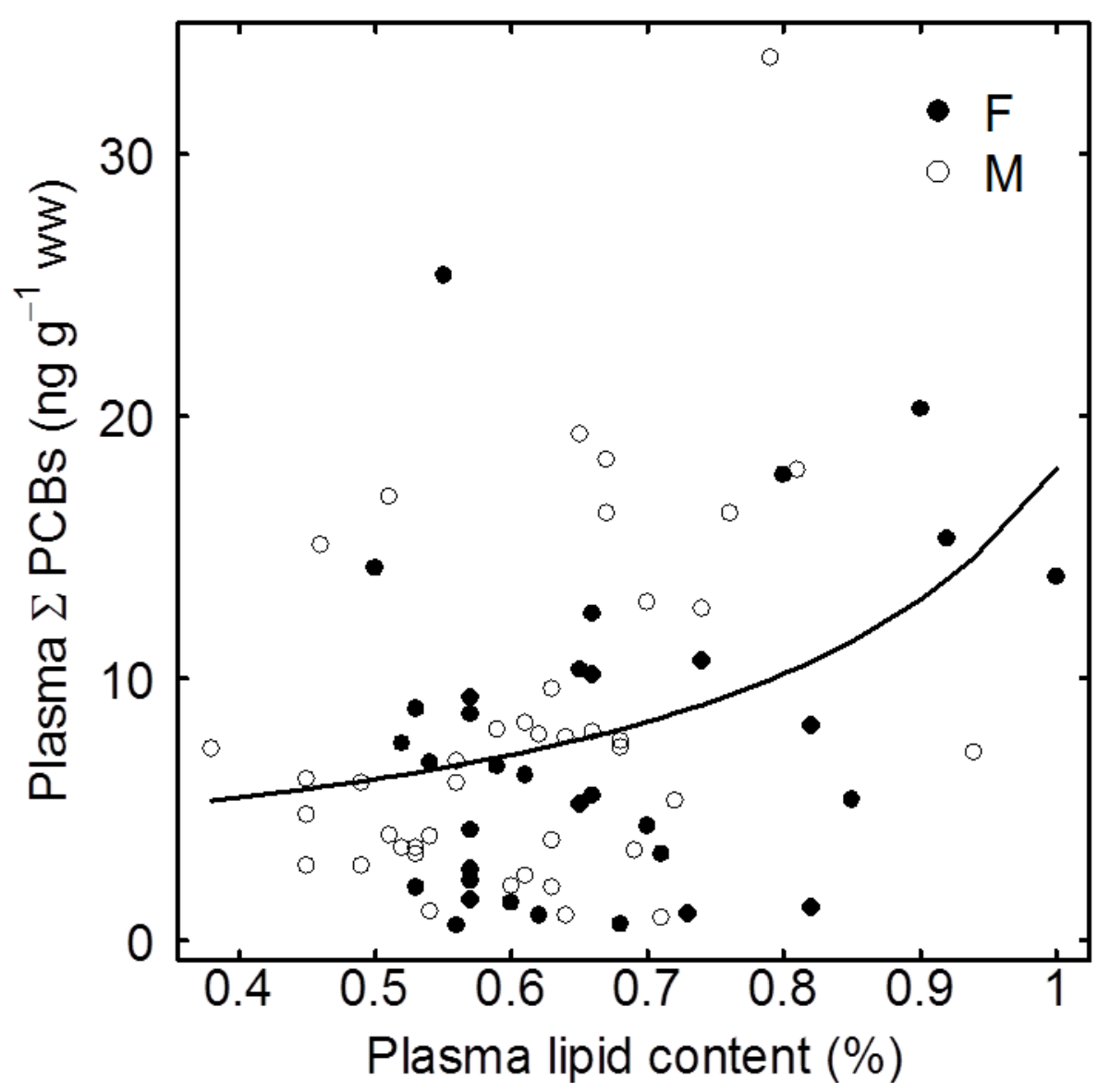

